\title{
Synthesis and Conformational Study of the First Triply-bridged Calix[6]azatubes
}

\author{
Stéphane Le Gac, Xianshun Zeng, Olivia Reinaud and Ivan Jabin*
}

\section{Supporting Information}

\begin{abstract}
Page S2: Figure S2. ${ }^{1} \mathrm{H}$ NMR $(300 \mathrm{MHz})$ spectra of 1 recorded at $\mathrm{rt}$ in $\mathrm{CDCl}_{3}$.
Page S3: Figure S3. ${ }^{1} \mathrm{H}$ NMR $(300 \mathrm{MHz})$ spectra of $\mathbf{2 b}$ recorded at $320 \mathrm{~K}$ in $\mathrm{CDCl}_{3}$.

Page S4: Figure $\mathrm{S} 4 .{ }^{1} \mathrm{H}$ NMR $(300 \mathrm{MHz})$ spectra of 3a recorded at $\mathrm{rt}$ in $\mathrm{CDCl}_{3}$.

Page S5: Figure S5. ${ }^{1} \mathrm{H}$ NMR $(300 \mathrm{MHz})$ spectra of $\mathbf{3 b}$ recorded at $\mathrm{rt}$ in $\mathrm{CDCl}_{3}$.

Page S6: Figure S6. ${ }^{1} \mathrm{H}$ NMR $(300 \mathrm{MHz})$ spectra of 5a recorded at $\mathrm{rt}$ in $\mathrm{CDCl}_{3}$.

Page S7: Figure S7. ${ }^{1} \mathrm{H}$ NMR $(300 \mathrm{MHz})$ spectra of $\mathbf{5 b}$ recorded at $\mathrm{rt}$ in $\mathrm{CDCl}_{3}$.

Page S8: Figure S8. ${ }^{1} \mathrm{H}$ NMR $(300 \mathrm{MHz})$ spectra of 7.3TFA recorded at $\mathrm{rt}$ in $\mathrm{CD}_{3} \mathrm{CN}$.

Page S9: Figure S9. ${ }^{1} \mathrm{H}$ NMR $(300 \mathrm{MHz})$ spectra of 8 recorded at $330 \mathrm{~K}$ in $\mathrm{CDCl}_{3}$.

Page S10: Figure S10. ${ }^{13} \mathrm{C}$ NMR (50 MHz) spectra of 1 recorded at $\mathrm{rt}$ in $\mathrm{CDCl}_{3}$.

Page S11: Figure S11. ${ }^{13} \mathrm{C}$ NMR $(75 \mathrm{MHz})$ spectra of $\mathbf{2 b}$ recorded at $\mathrm{rt}$ in $\mathrm{CDCl}_{3}$.

Page S12: Figure S12. ${ }^{13} \mathrm{C} \mathrm{NMR} \mathrm{(50} \mathrm{MHz)} \mathrm{spectra} \mathrm{of} \mathrm{3a} \mathrm{recorded} \mathrm{at} \mathrm{rt}$ in $\mathrm{CDCl}_{3}$.

Page S13: Figure S13. ${ }^{13} \mathrm{C}$ NMR $(75 \mathrm{MHz})$ spectra of $\mathbf{3 b}$ recorded at $\mathrm{rt}$ in $\mathrm{CDCl}_{3}$.

Page S14: Figure S14. ${ }^{13} \mathrm{C}$ NMR $(75 \mathrm{MHz})$ spectra of 5 a recorded at $\mathrm{rt}$ in $\mathrm{CDCl}_{3}$.

Page S15: Figure S15. ${ }^{13} \mathrm{C}$ NMR $(75 \mathrm{MHz})$ spectra of $\mathbf{5 b}$ recorded at $\mathrm{rt}$ in $\mathrm{CDCl}_{3}$.

Page S16: Figure S16. ${ }^{13} \mathrm{C}$ NMR $(75 \mathrm{MHz})$ spectra of 6 a recorded at $\mathrm{rt}$ in $\mathrm{CDCl}_{3}$.

Page S17: Figure S17. ${ }^{13} \mathrm{C}$ NMR $(75 \mathrm{MHz})$ spectra of $6 \mathbf{b}$ recorded at $\mathrm{rt}$ in $\mathrm{CDCl}_{3}$.

Page S18: Figure S18. ${ }^{13} \mathrm{C}$ NMR $(75 \mathrm{MHz})$ spectra of 7 recorded at $\mathrm{rt}$ in $\mathrm{CD}_{3} \mathrm{CN}$.

Page S19: Figure S19. ${ }^{13} \mathrm{C}$ NMR $(75 \mathrm{MHz})$ spectra of 8 recorded at $\mathrm{rt}$ in $\mathrm{CDCl}_{3}$.

Page S20: Figure S20. HMQC spectra of 1 recorded at $\mathrm{rt}$ in $\mathrm{CDCl}_{3}$.

Page S21: Figure S21. HMQC spectra of $\mathbf{2 b}$ recorded at $320 \mathrm{~K}$ in $\mathrm{CDCl}_{3}$.

Page S22: Figure S22. $\mathrm{HMBC}$ spectra of $3 \mathbf{a}$ recorded at $\mathrm{rt}$ in $\mathrm{CDCl}_{3}$.

Page S23: Figure S23. HMQC spectra of 3a recorded at $\mathrm{rt}$ in $\mathrm{CDCl}_{3}$.

Page S24: Figure S24. HMBC spectra of $\mathbf{3 b}$ recorded at $\mathrm{rt}$ in $\mathrm{CDCl}_{3}$.

Page S25: Figure S25. HMQC spectra of $\mathbf{3 b}$ recorded at $\mathrm{rt}$ in $\mathrm{CDCl}_{3}$.

Page S26: Figure S26. HMBC spectra of 5a recorded at $\mathrm{rt}$ in $\mathrm{CDCl}_{3}$.

Page S27: Figure S27. HMQC spectra of 5a recorded at $\mathrm{rt}$ in $\mathrm{CDCl}_{3}$.

Page S28: Figure S28. HMBC spectra of $\mathbf{5 b}$ recorded at $\mathrm{rt}$ in $\mathrm{CDCl}_{3}$.

Page S29: Figure S29. HMQC spectra of $\mathbf{5 b}$ recorded at $\mathrm{rt}$ in $\mathrm{CDCl}_{3}$.

Page S30: Figure S30. $\mathrm{HMBC}$ spectra of $6 \mathbf{6}$ recorded at rt in $\mathrm{CDCl}_{3}$.

Page S31: Figure S31. HMQC spectra of 6 a recorded at $\mathrm{rt}$ in $\mathrm{CDCl}_{3}$.

Page S32: Figure S32. HMBC spectra of $6 \mathbf{b}$ recorded at $\mathrm{rt}$ in $\mathrm{CDCl}_{3}$.

Page S33: Figure S33. HMQC spectra of $\mathbf{6 b}$ recorded at $\mathrm{rt}$ in $\mathrm{CDCl}_{3}$.

Page S34: Figure S34. HMBC spectra of 7 recorded at $\mathrm{rt}$ in $\mathrm{CD}_{3} \mathrm{CN}$.

Page S35: Figure S35. HMQC spectra of 7 recorded at $\mathrm{rt}$ in $\mathrm{CD}_{3} \mathrm{CN}$.

Page S36: Figure S36. HMBC spectra of 8 recorded at $330 \mathrm{~K}$ in $\mathrm{CDCl}_{3}$.

Page S37: Figure S37. HMQC spectra of 8 recorded at $330 \mathrm{~K}$ in $\mathrm{CDCl}_{3}$.

Page S38: Figure S38. NOESY spectra of 7 recorded at $\mathrm{rt}$ in $\mathrm{CD}_{3} \mathrm{CN}$.

Page S39: Figure S39. NOESY spectra of 7 recorded at $\mathrm{rt}$ in $\mathrm{CDCl}_{3}$.

Page S40: General Experimental Procedures.
\end{abstract}

Residual solvent and water are labelled S and W respectively. 

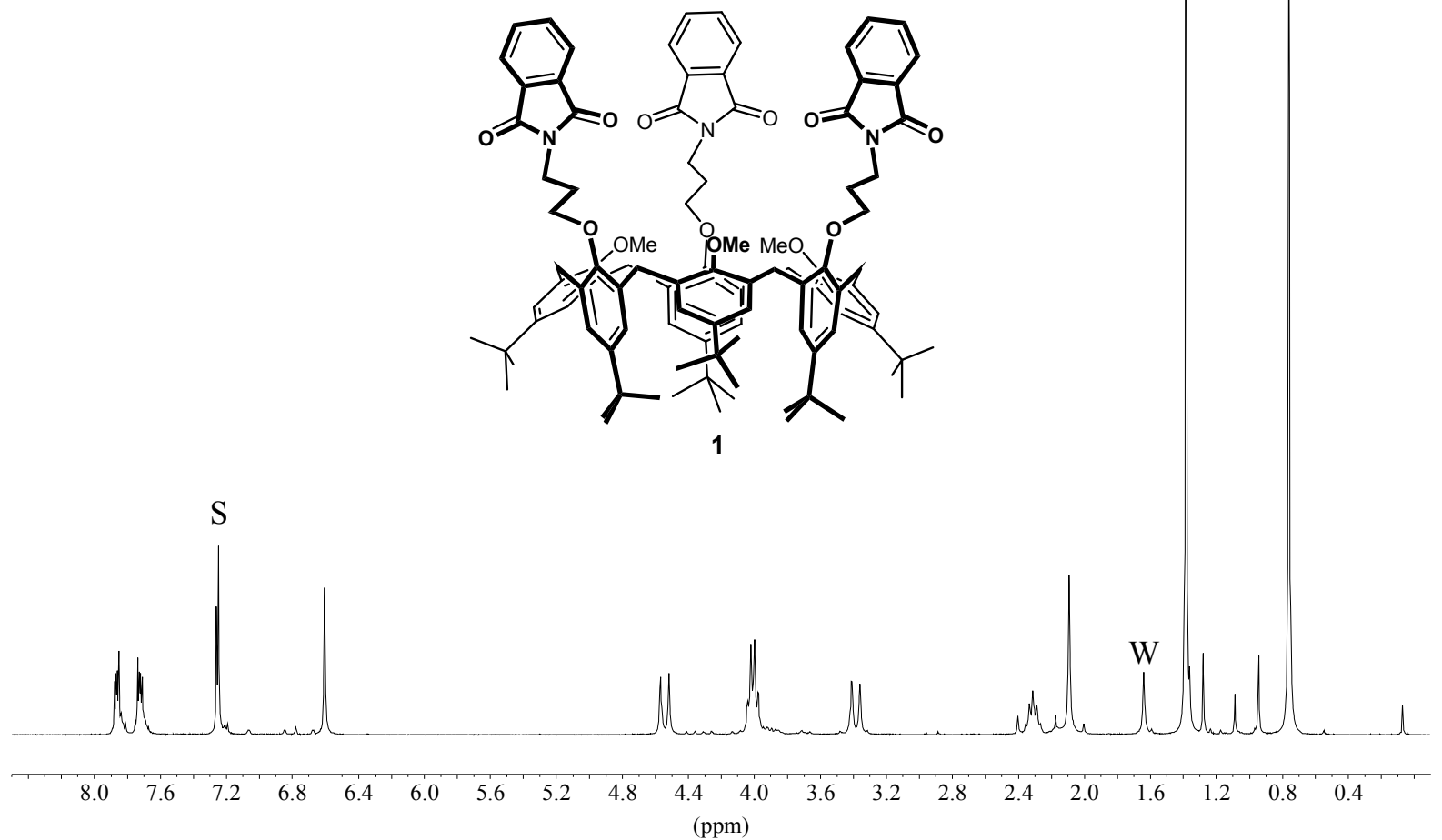

Figure S2. ${ }^{1} \mathrm{H}$ NMR $(300 \mathrm{MHz})$ spectra of 1 recorded at $\mathrm{rt}$ in $\mathrm{CDCl}_{3}$. 


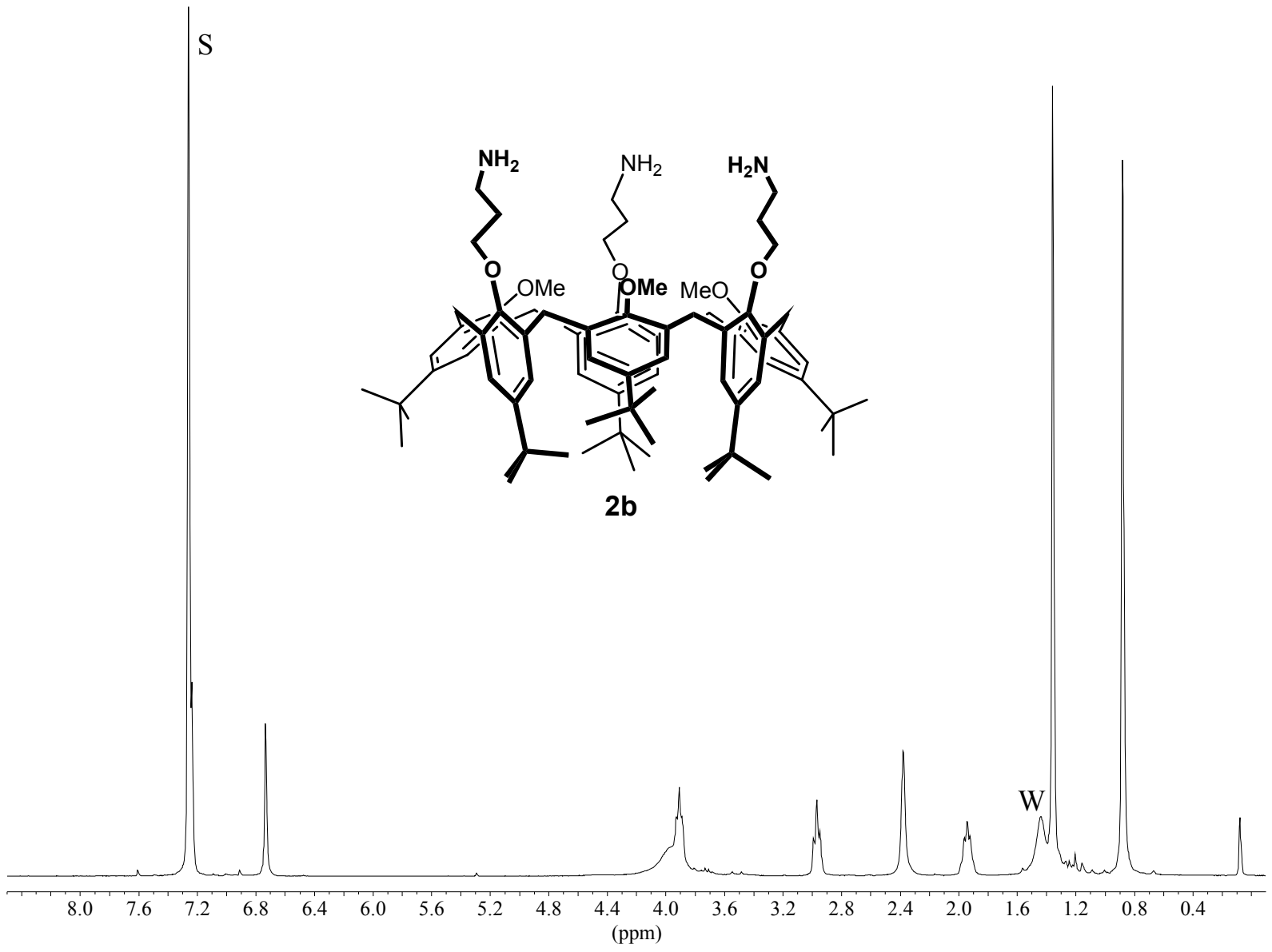

Figure S3. ${ }^{1} \mathrm{H}$ NMR (300 MHz) spectra of $\mathbf{2 b}$ recorded at $320 \mathrm{~K}$ in $\mathrm{CDCl}_{3}$. 


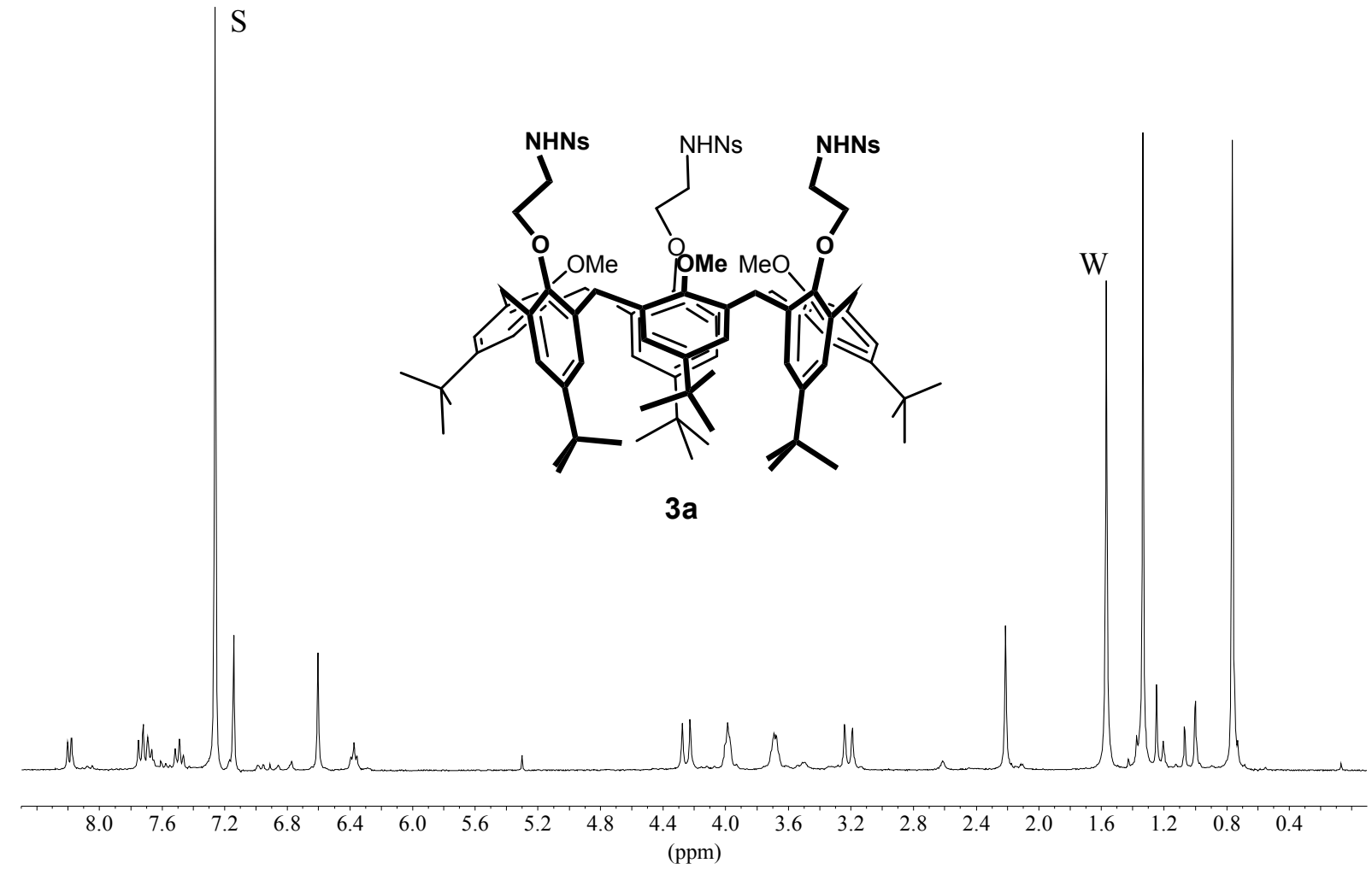

Figure S4. ${ }^{1} \mathrm{H}$ NMR (300 MHz) spectra of 3a recorded at $\mathrm{rt}$ in $\mathrm{CDCl}_{3}$. 


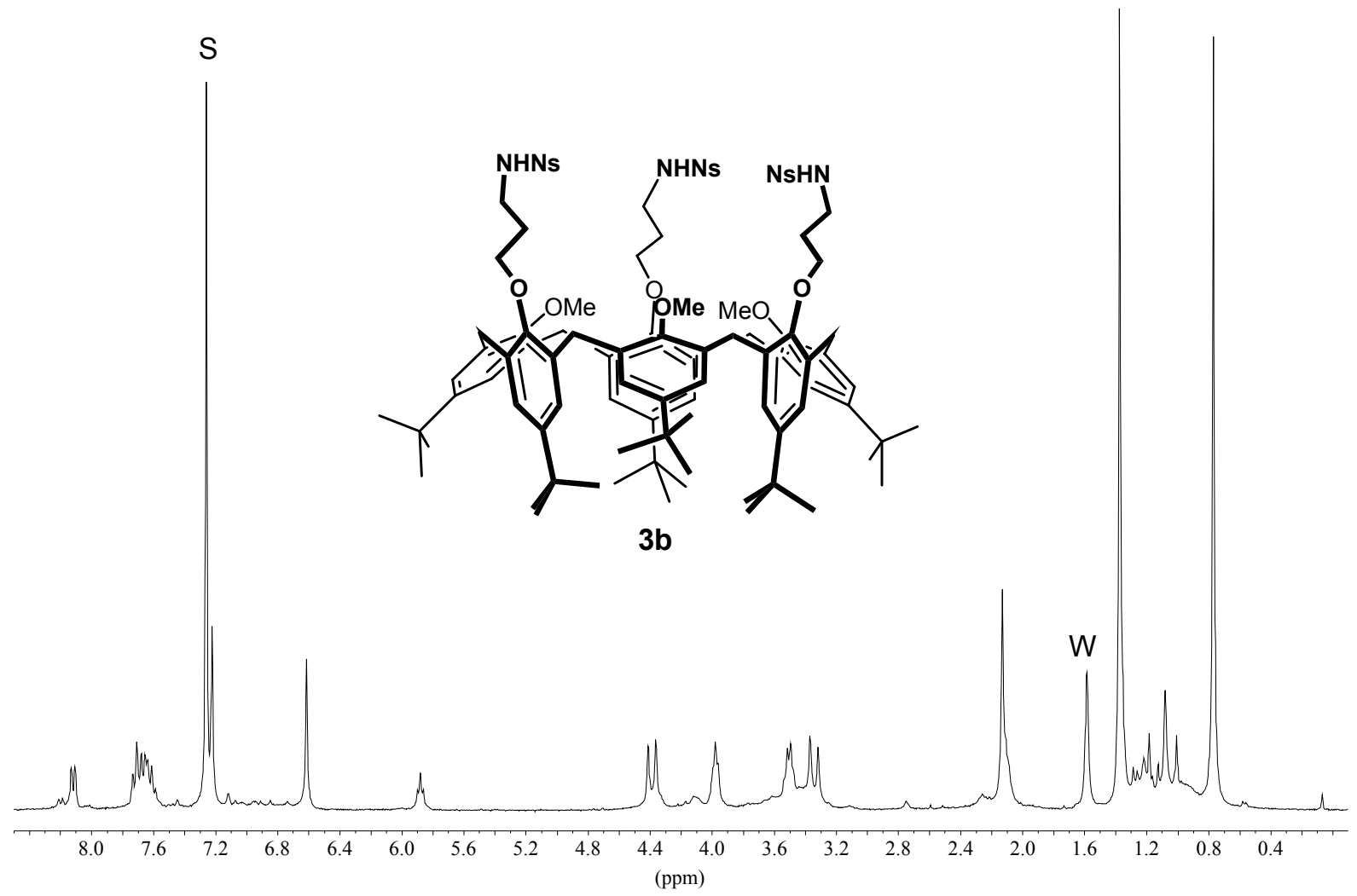

Figure S5. ${ }^{1} \mathrm{H}$ NMR (300 MHz) spectra of $\mathbf{3 b}$ recorded at $\mathrm{rt}$ in $\mathrm{CDCl}_{3}$. 


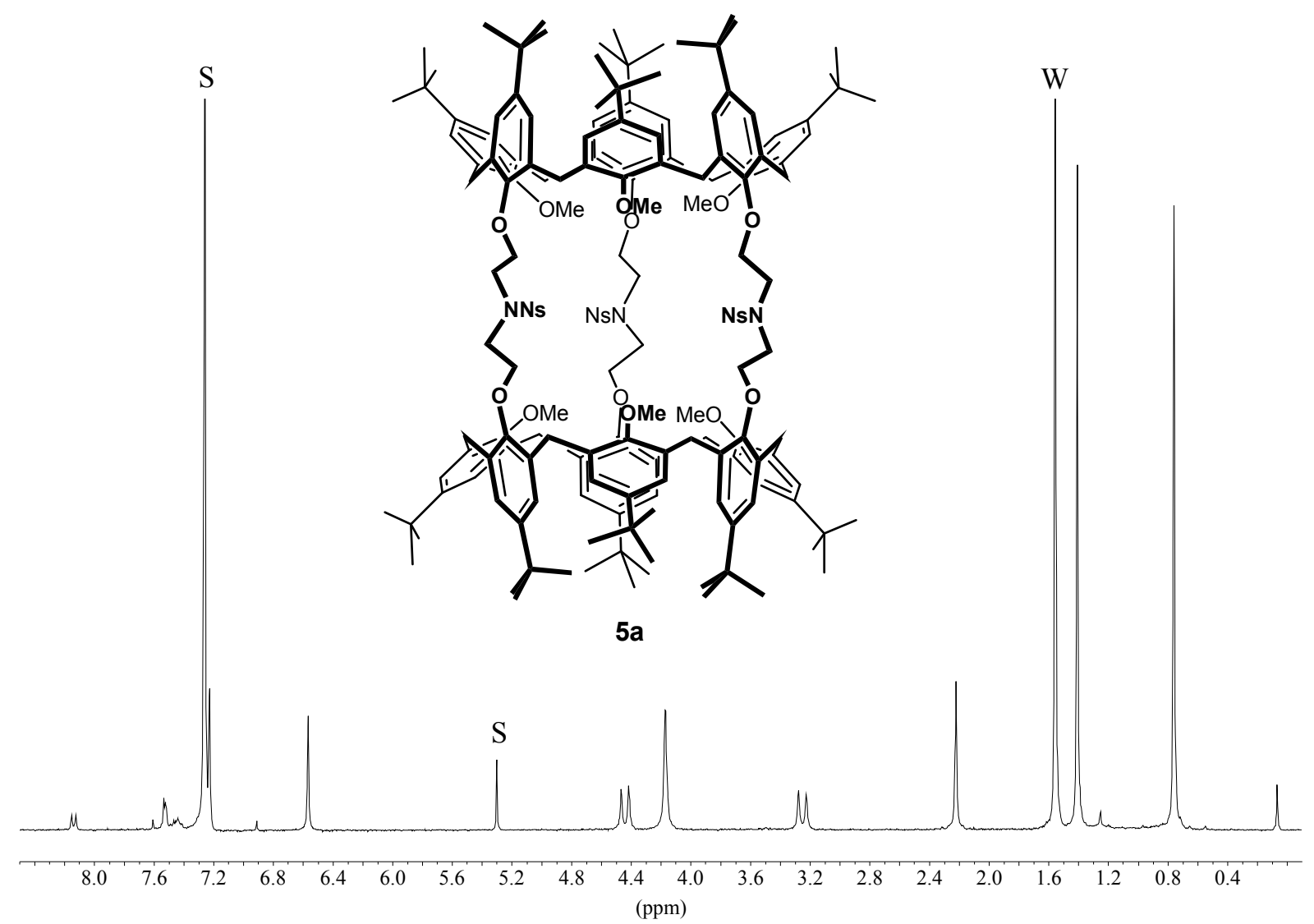

Figure S6. ${ }^{1} \mathrm{H}$ NMR $(300 \mathrm{MHz})$ spectra of 5 a recorded at $\mathrm{rt}$ in $\mathrm{CDCl}_{3}$. 


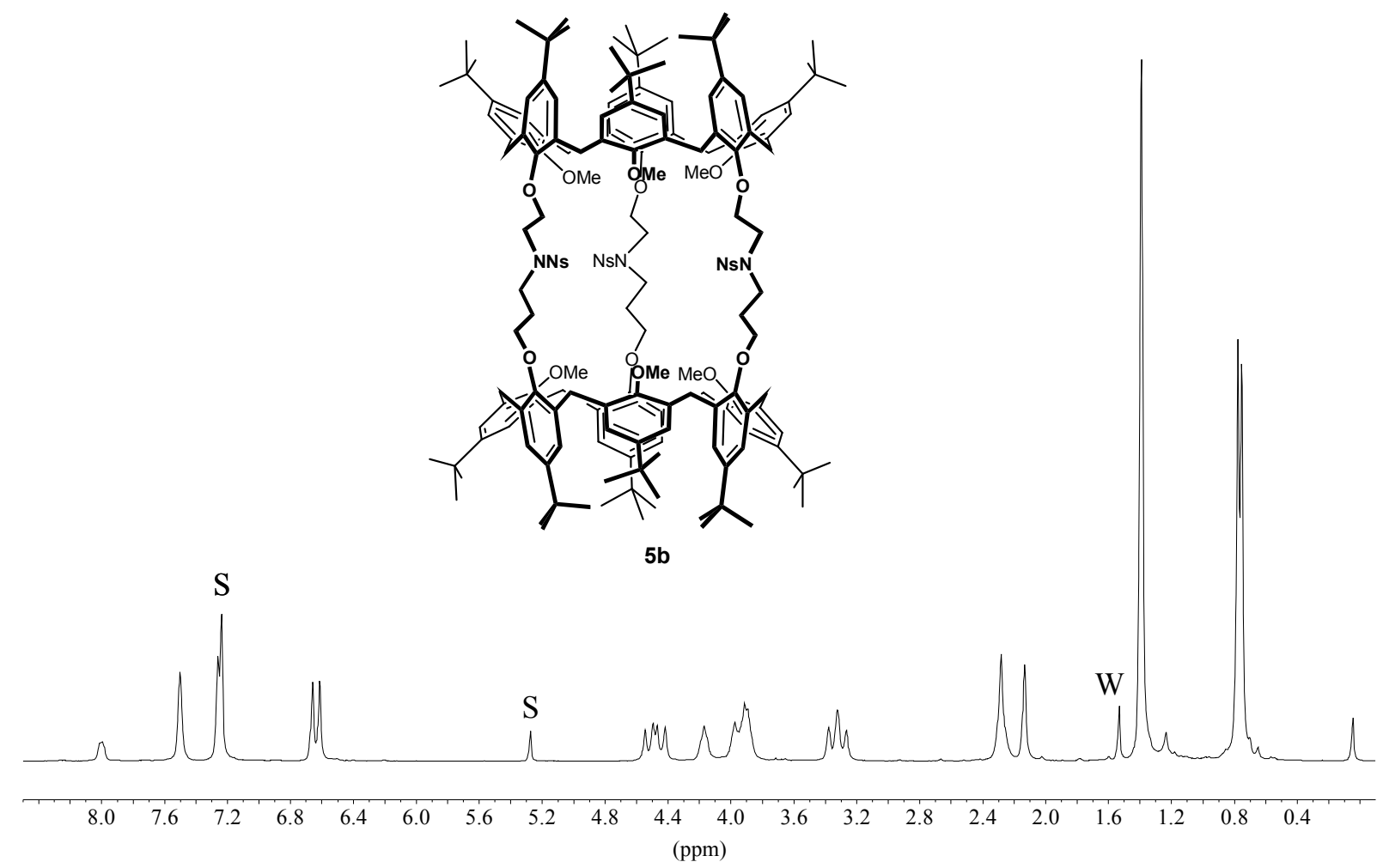

Figure S7. ${ }^{1} \mathrm{H}$ NMR (300 MHz) spectra of $\mathbf{5 b}$ recorded at $\mathrm{rt}$ in $\mathrm{CDCl}_{3}$. 


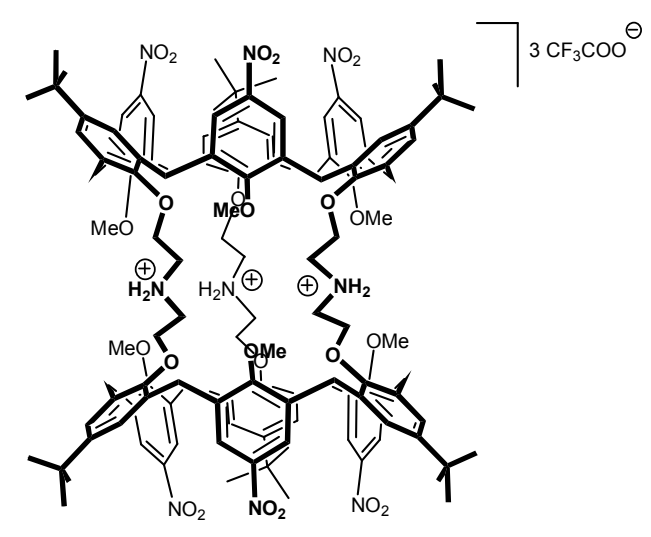

7.3TFA

$\begin{array}{lllllllllllllllllllllll}8.8 & 8.4 & 8.0 & 7.6 & 7.2 & 6.8 & 6.4 & 6.0 & 5.6 & 5.2 & 4.8 & (\mathrm{ppm}) & 4.0 & 3.6 & 3.2 & 2.8 & 2.4 & 2.0 & 1.6 & 1.2 & 0.8 & 0.4\end{array}$

Figure S8. ${ }^{1} \mathrm{H}$ NMR $(300 \mathrm{MHz})$ spectra of 7.3TFA recorded at $\mathrm{rt}$ in $\mathrm{CD}_{3} \mathrm{CN}$. 


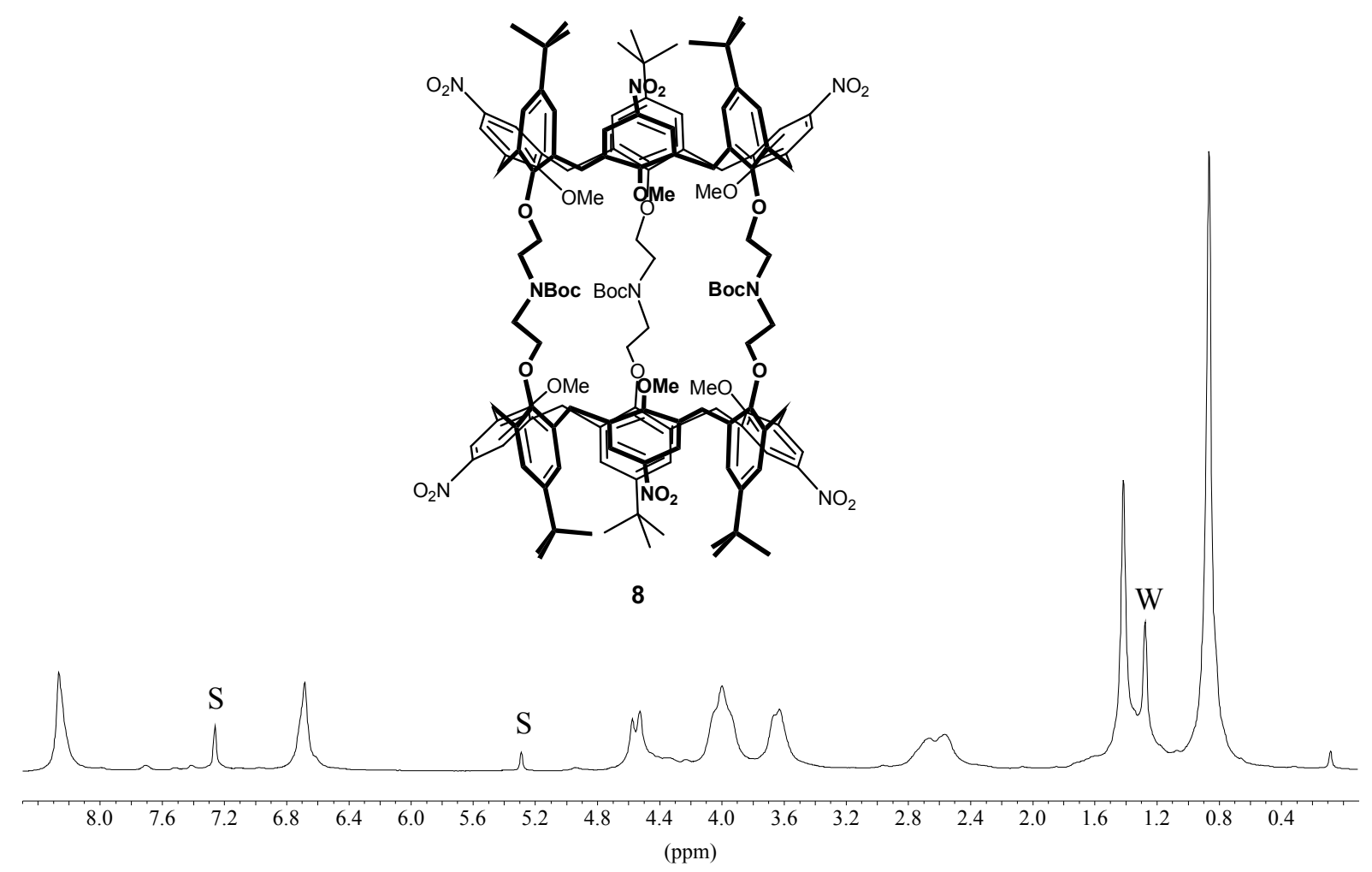

Figure S9. ${ }^{1} \mathrm{H}$ NMR $(300 \mathrm{MHz})$ spectra of 8 recorded at $330 \mathrm{~K}$ in $\mathrm{CDCl}_{3}$. 

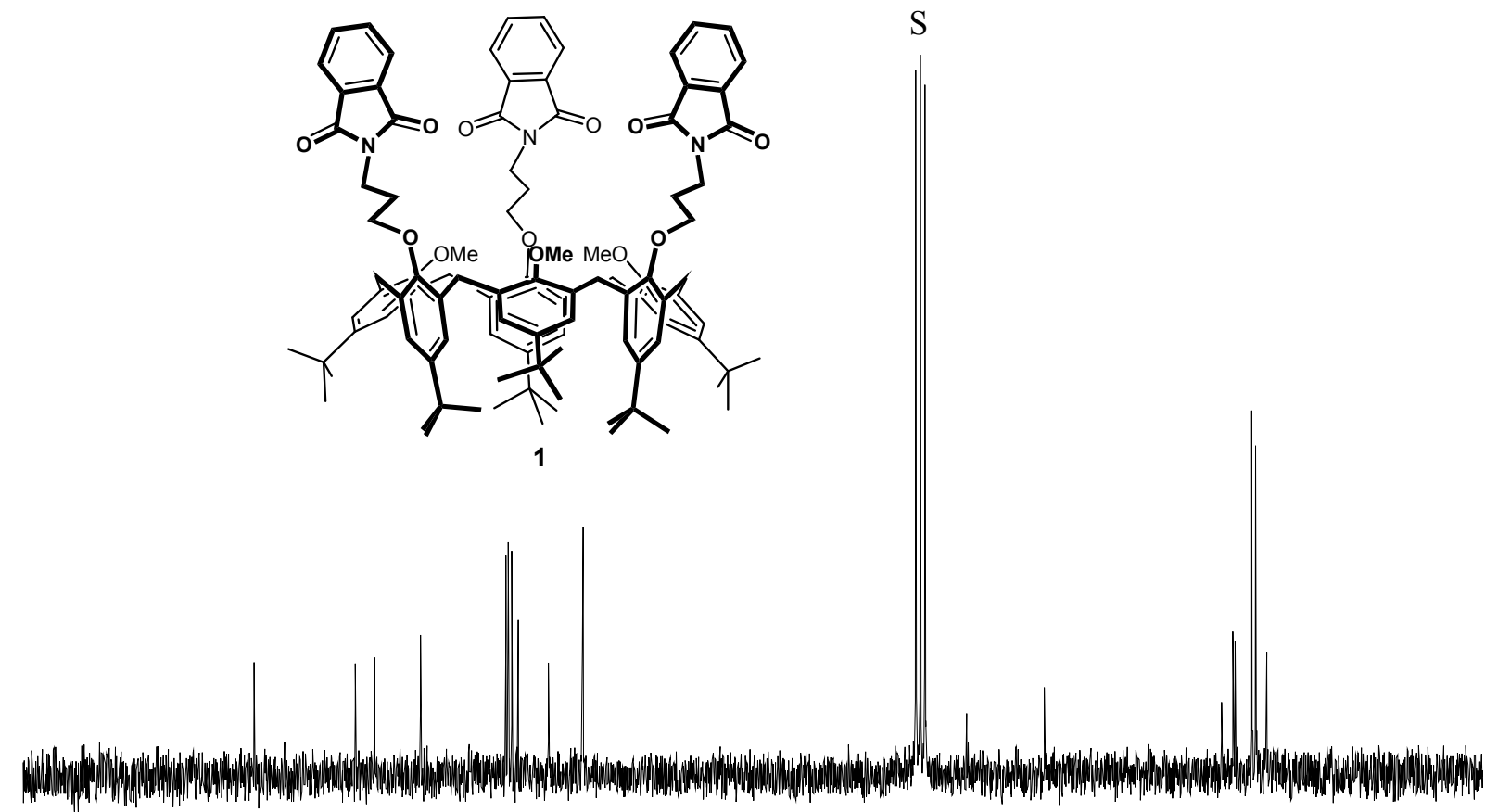

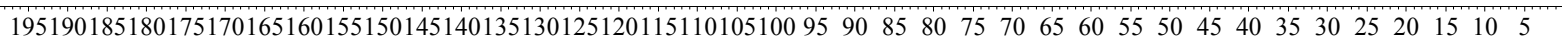
(ppm)

Figure S10. ${ }^{13} \mathrm{C}$ NMR (50 MHz) spectra of 1 recorded at $\mathrm{rt}$ in $\mathrm{CDCl}_{3}$. 


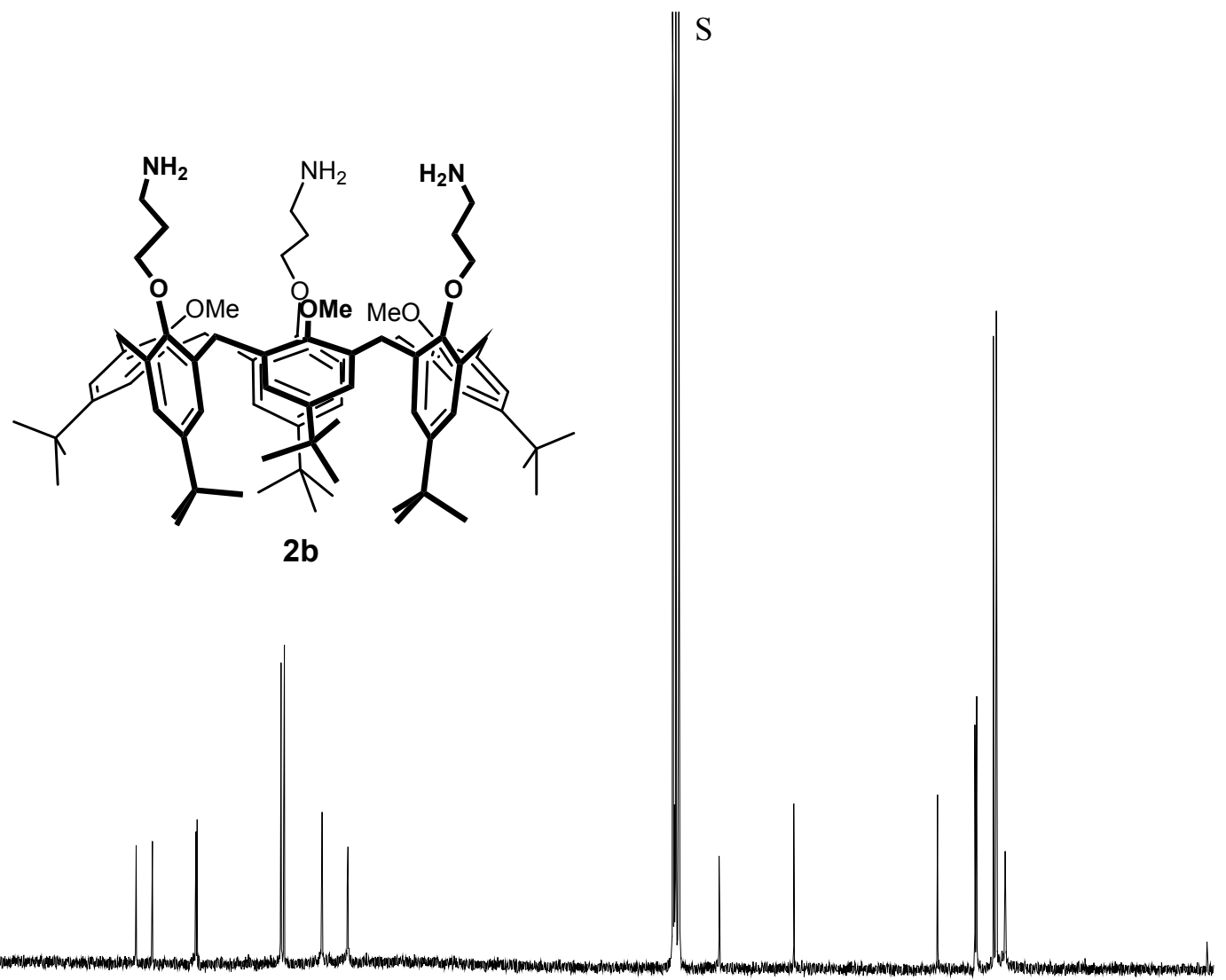

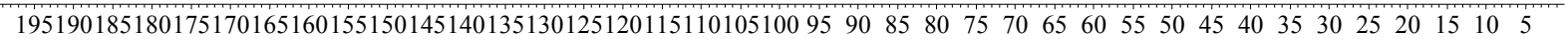
(ppm)

Figure S11. ${ }^{13} \mathrm{C}$ NMR $(75 \mathrm{MHz})$ spectra of $\mathbf{2} \mathbf{b}$ recorded at $\mathrm{rt}$ in $\mathrm{CDCl}_{3}$. 


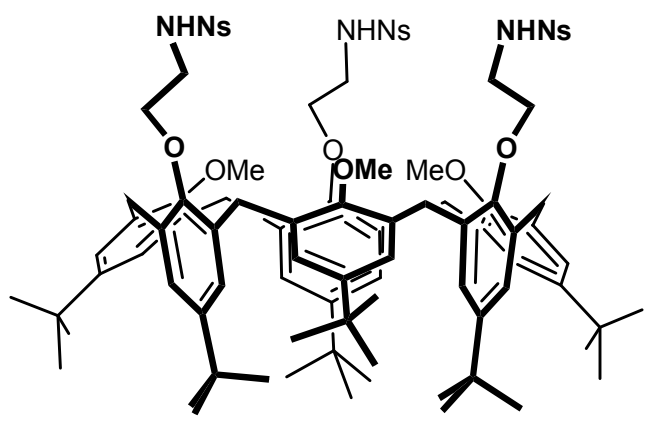

$3 a$

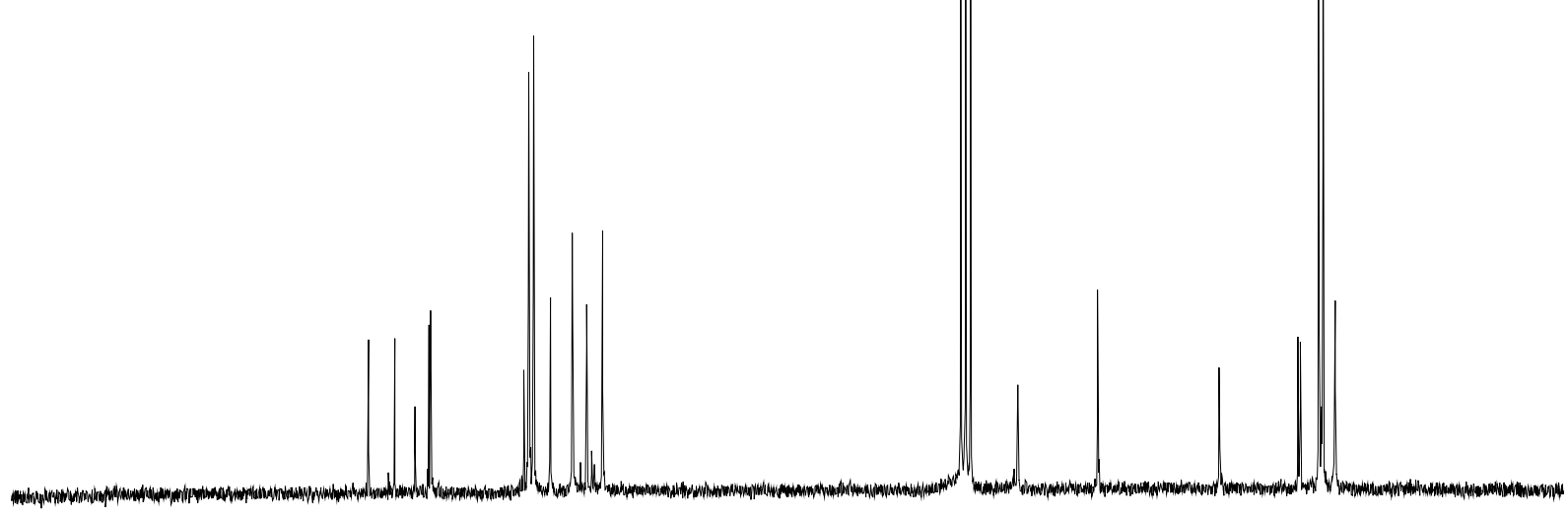

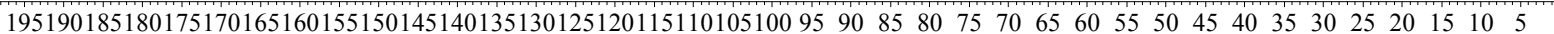
(ppm)

Figure S12. ${ }^{13} \mathrm{C}$ NMR $(50 \mathrm{MHz})$ spectra of 3a recorded at $\mathrm{rt}$ in $\mathrm{CDCl}_{3}$. 

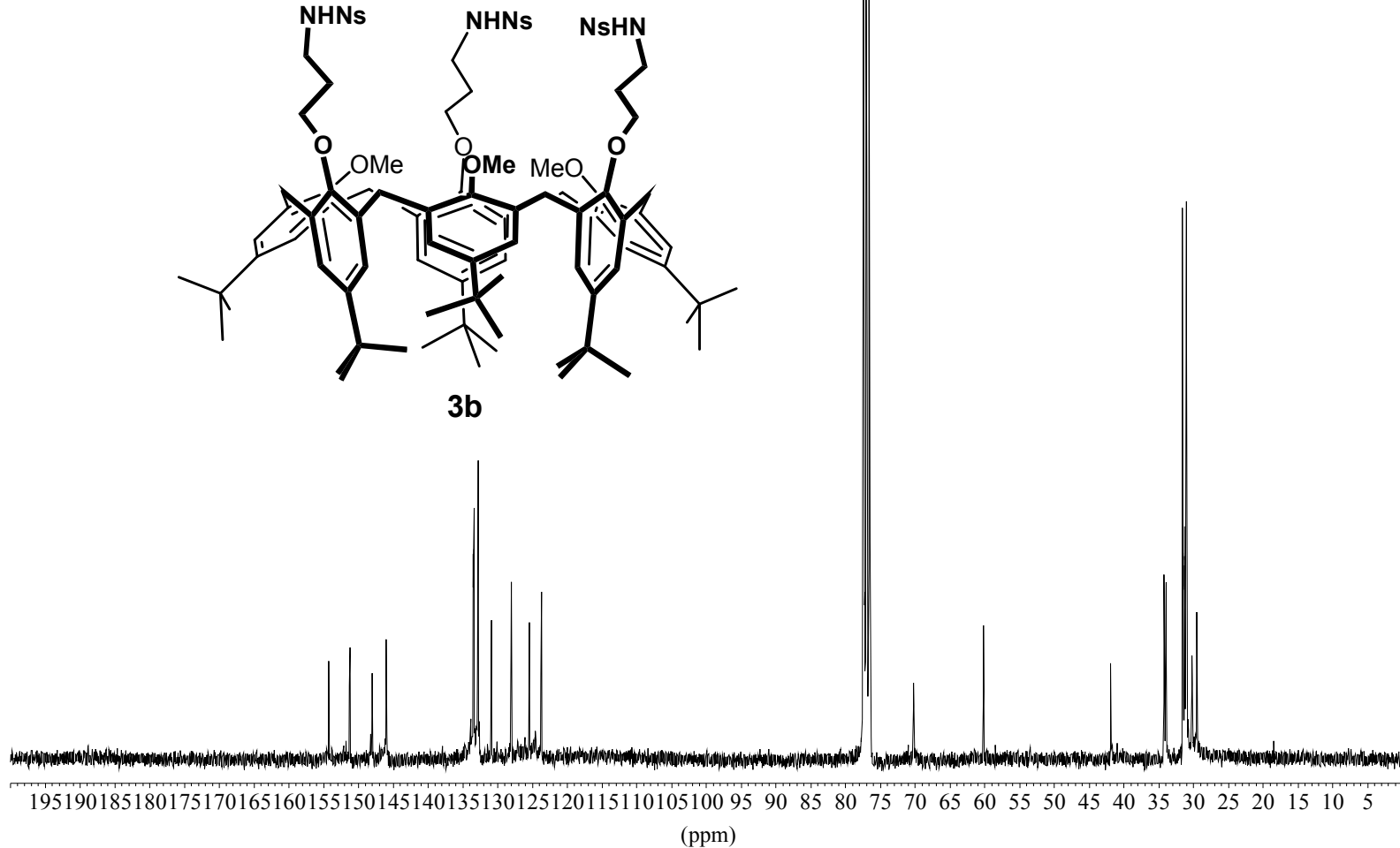

Figure S13. ${ }^{13} \mathrm{C}$ NMR $(75 \mathrm{MHz})$ spectra of $\mathbf{3 b}$ recorded at $\mathrm{rt}$ in $\mathrm{CDCl}_{3}$. 


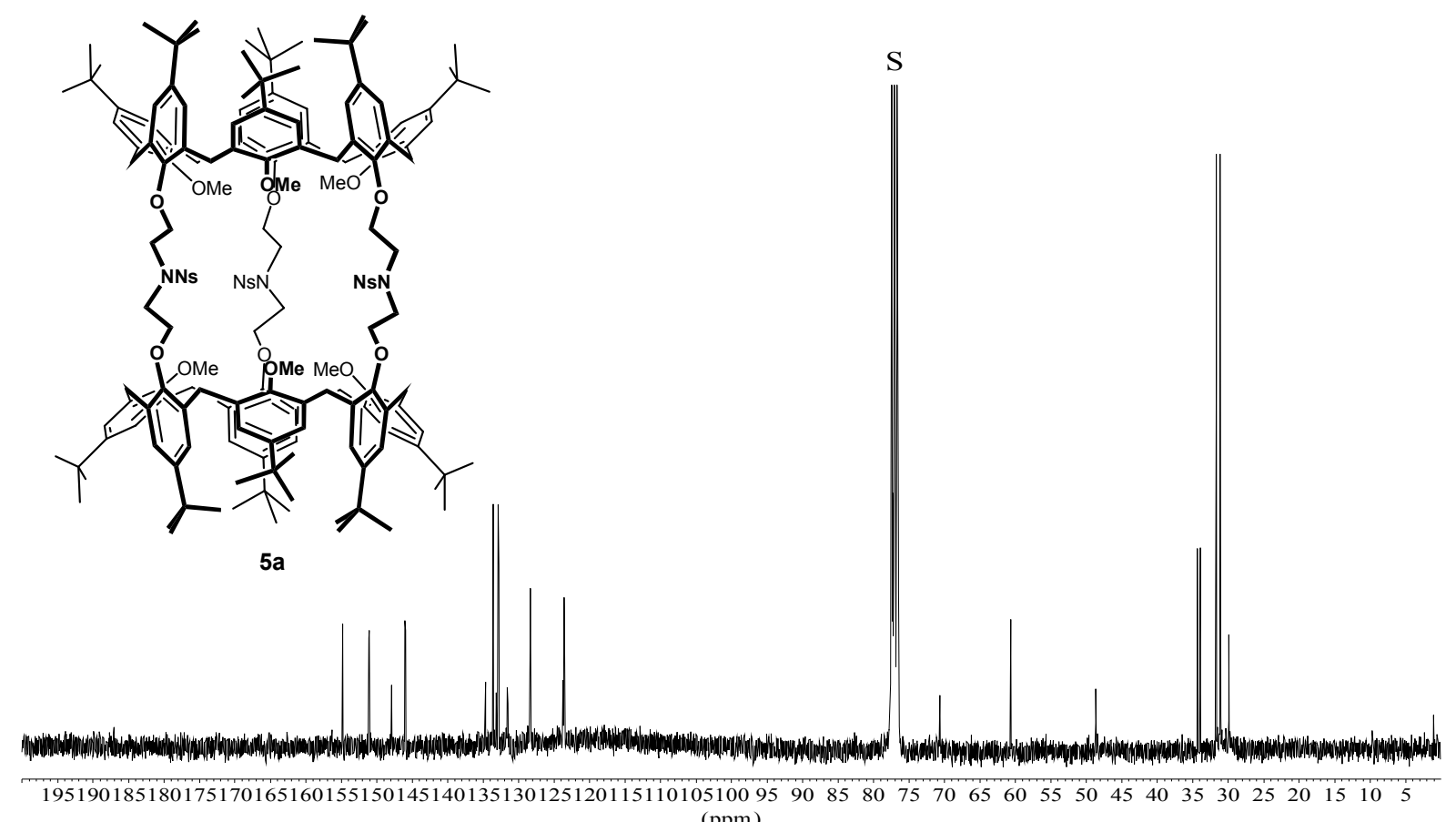
(ppm)

Figure S14. ${ }^{13} \mathrm{C}$ NMR $(75 \mathrm{MHz})$ spectra of 5 a recorded at $\mathrm{rt}$ in $\mathrm{CDCl}_{3}$. 


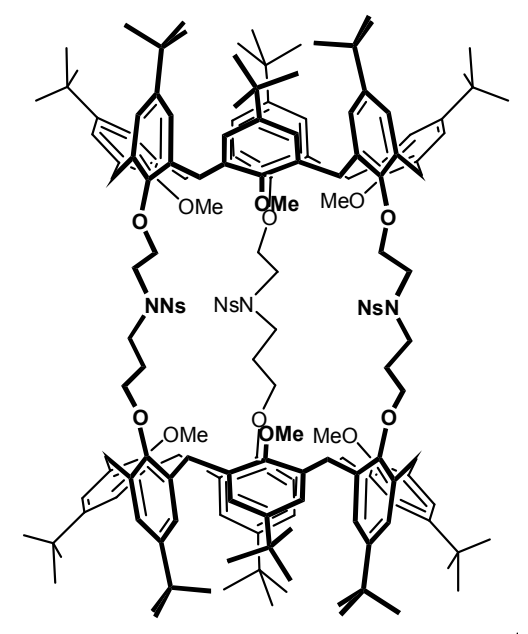

$5 b$

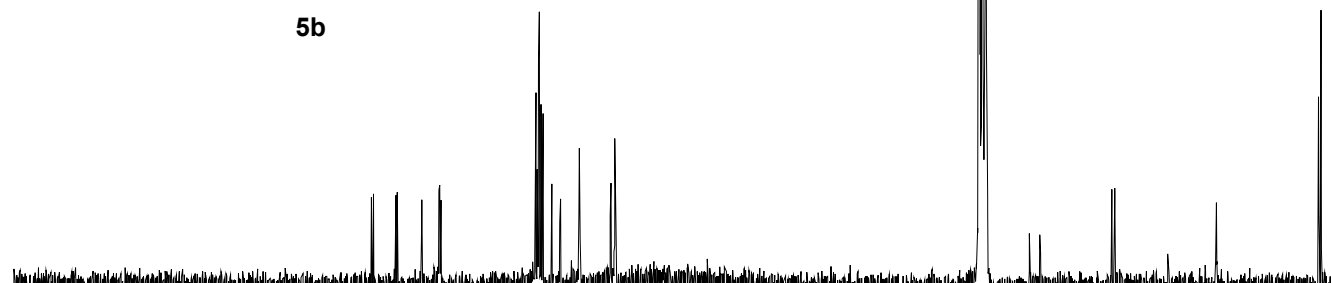

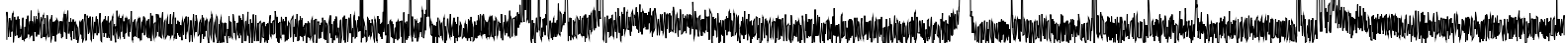
$1951901851801751701651601551501451401351301251201151101051009590 \quad 858075 \quad 7065 \quad 6055 \quad 504540 \quad 353025 \quad 2015 \quad 10 \quad 5$ (ppm)

Figure S15. ${ }^{13} \mathrm{C}$ NMR $(75 \mathrm{MHz})$ spectra of $\mathbf{5 b}$ recorded at $\mathrm{rt}$ in $\mathrm{CDCl}_{3}$. 

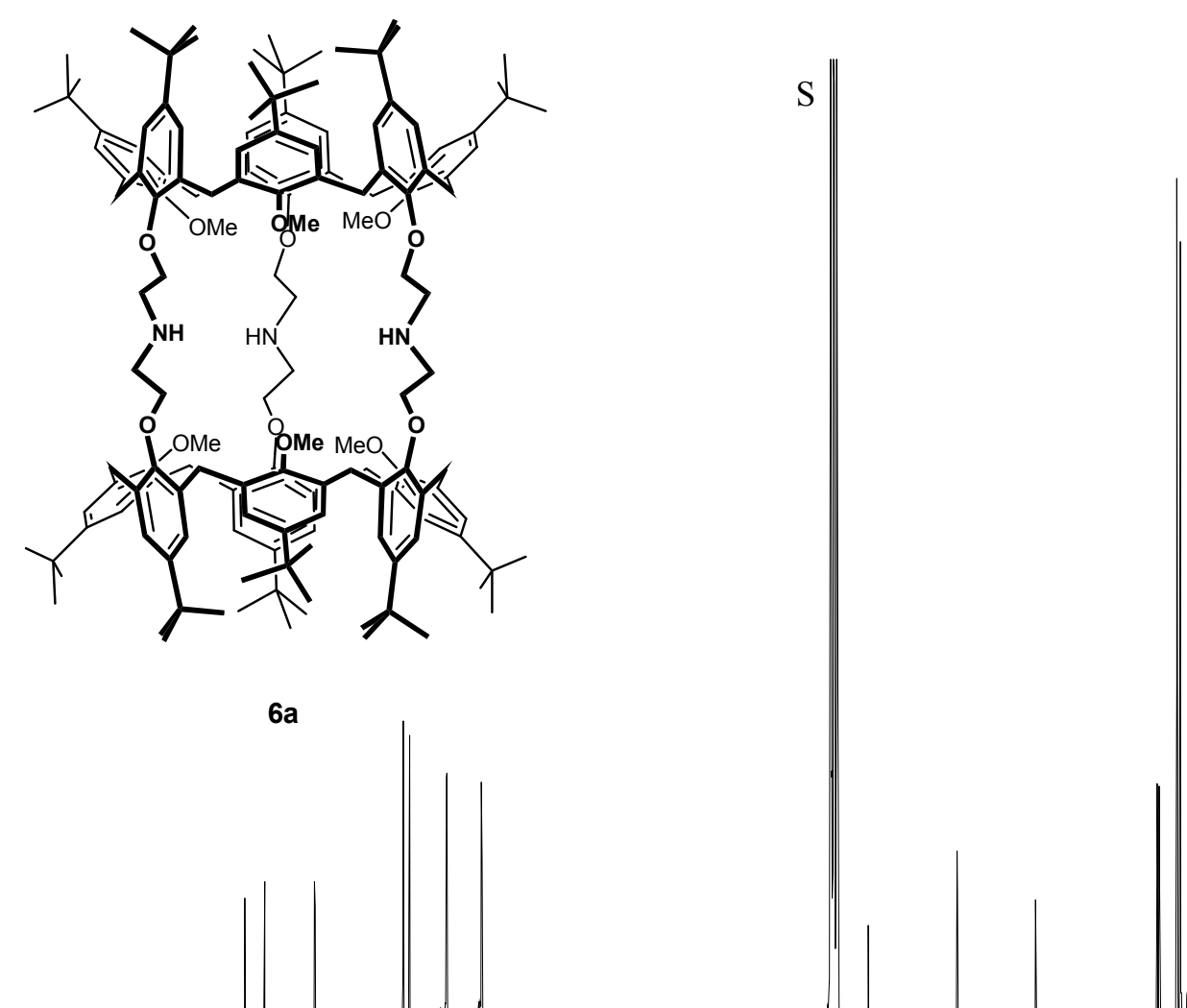

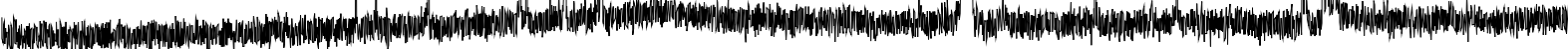
$19519018518017517016516015515014514013513012512011511010510095 \quad 90 \quad 858075 \quad 7065 \quad 60 \quad 55 \quad 50 \quad 45 \quad 40 \quad 35 \quad 30 \quad 25 \quad 2015 \quad 10 \quad 5$ (ppm)

Figure S16. ${ }^{13} \mathrm{C}$ NMR $(75 \mathrm{MHz})$ spectra of $\mathbf{6 a}$ recorded at $\mathrm{rt}$ in $\mathrm{CDCl}_{3}$. 


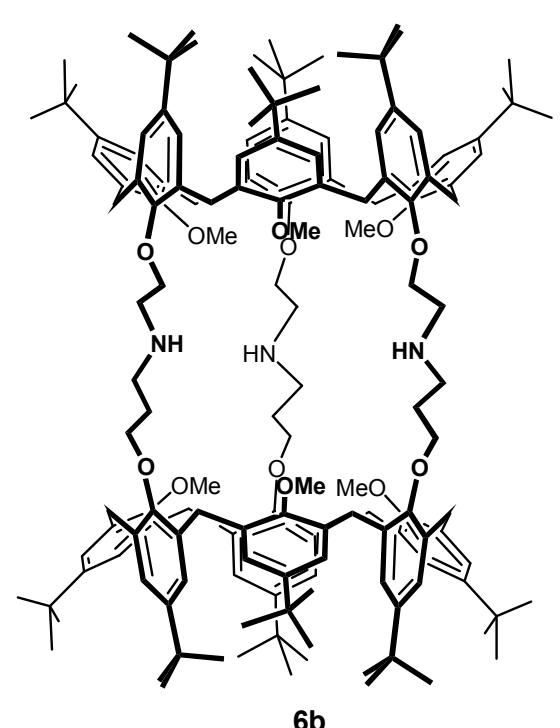

$6 \mathrm{~b}$

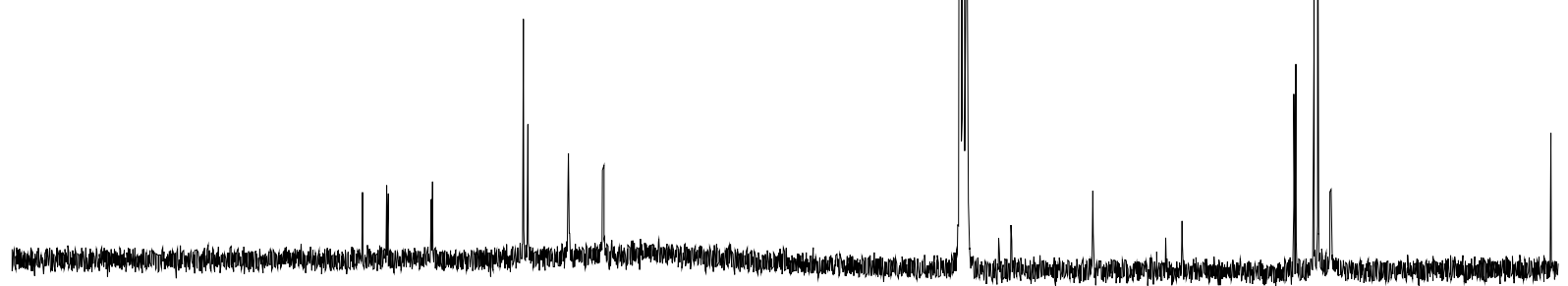

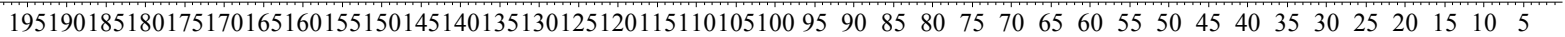
(ppm)

Figure S17. ${ }^{13} \mathrm{C}$ NMR $(75 \mathrm{MHz})$ spectra of $\mathbf{6 b}$ recorded at $\mathrm{rt}$ in $\mathrm{CDCl}_{3}$. 

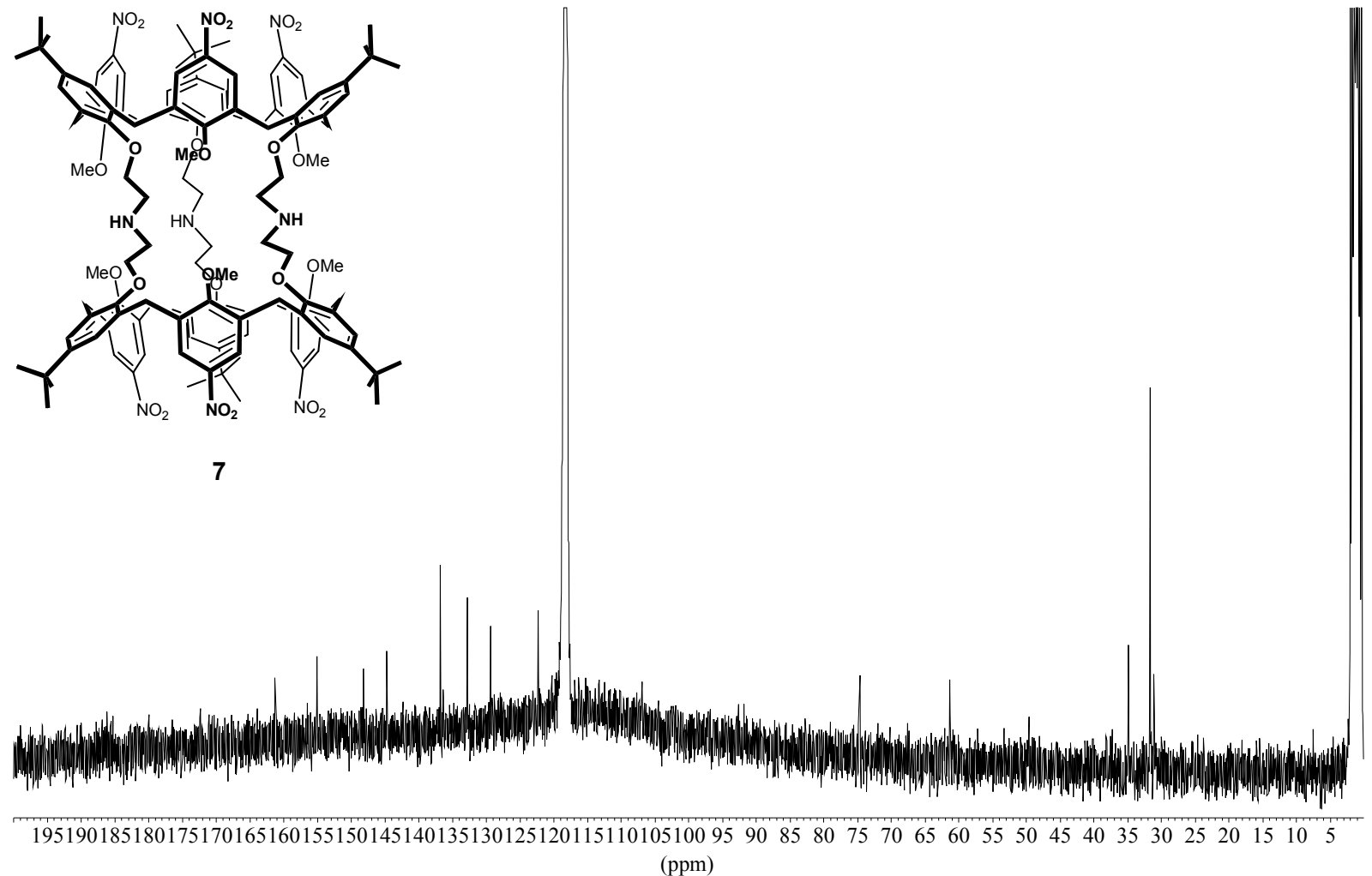

Figure S18. ${ }^{13} \mathrm{C}$ NMR $(75 \mathrm{MHz})$ spectra of 7 recorded at $\mathrm{rt}$ in $\mathrm{CD}_{3} \mathrm{CN}$. 

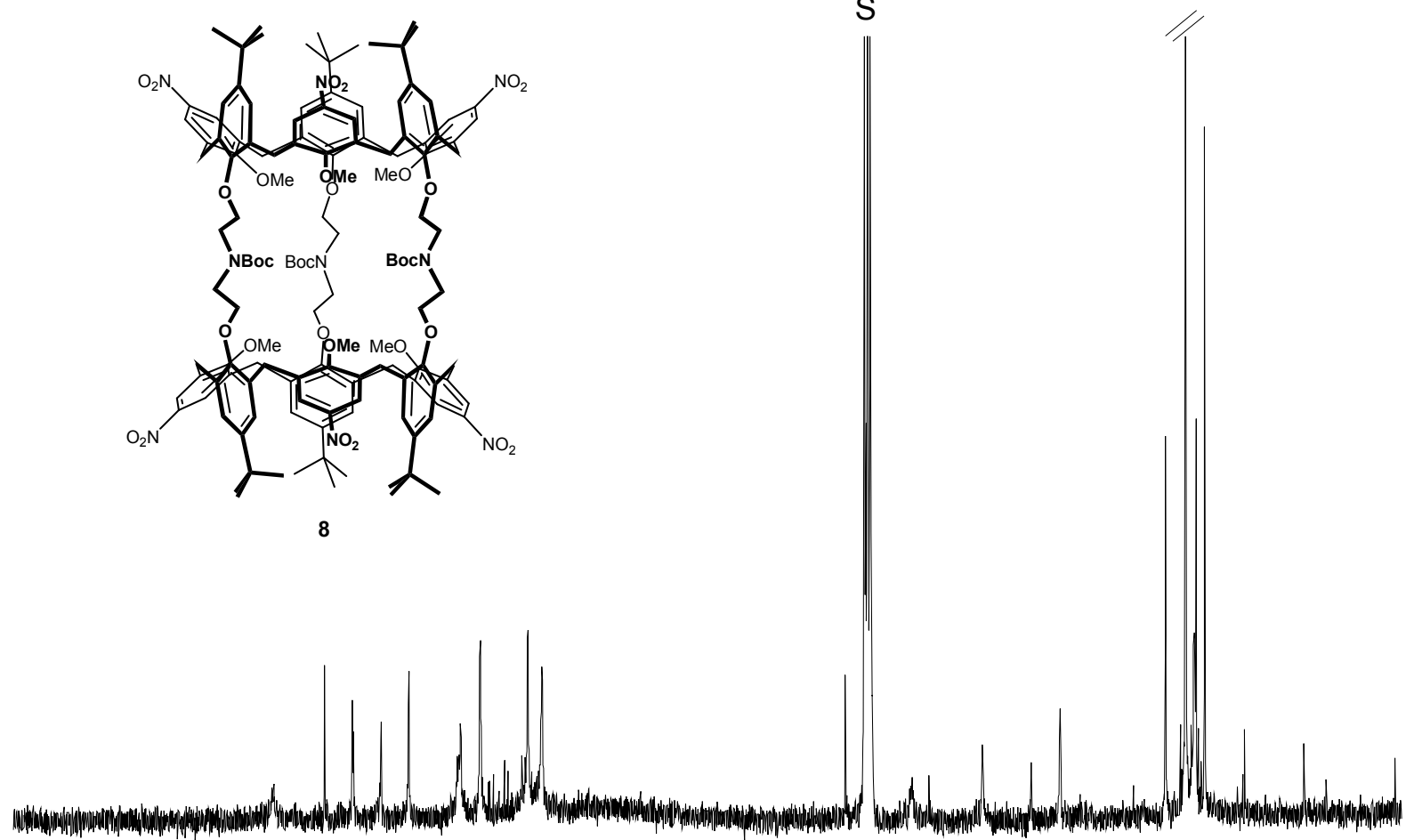
$1951901851801751701651601551501451401351301251201151101051009590 \quad 85807570 \quad 6560 \quad 55 \quad 50 \quad 4540 \quad 353025 \quad 201510 \quad 5$ (ppm)

Figure S19. ${ }^{13} \mathrm{C}$ NMR (75 MHz) spectra of 8 recorded at $\mathrm{rt}$ in $\mathrm{CDCl}_{3}$. 


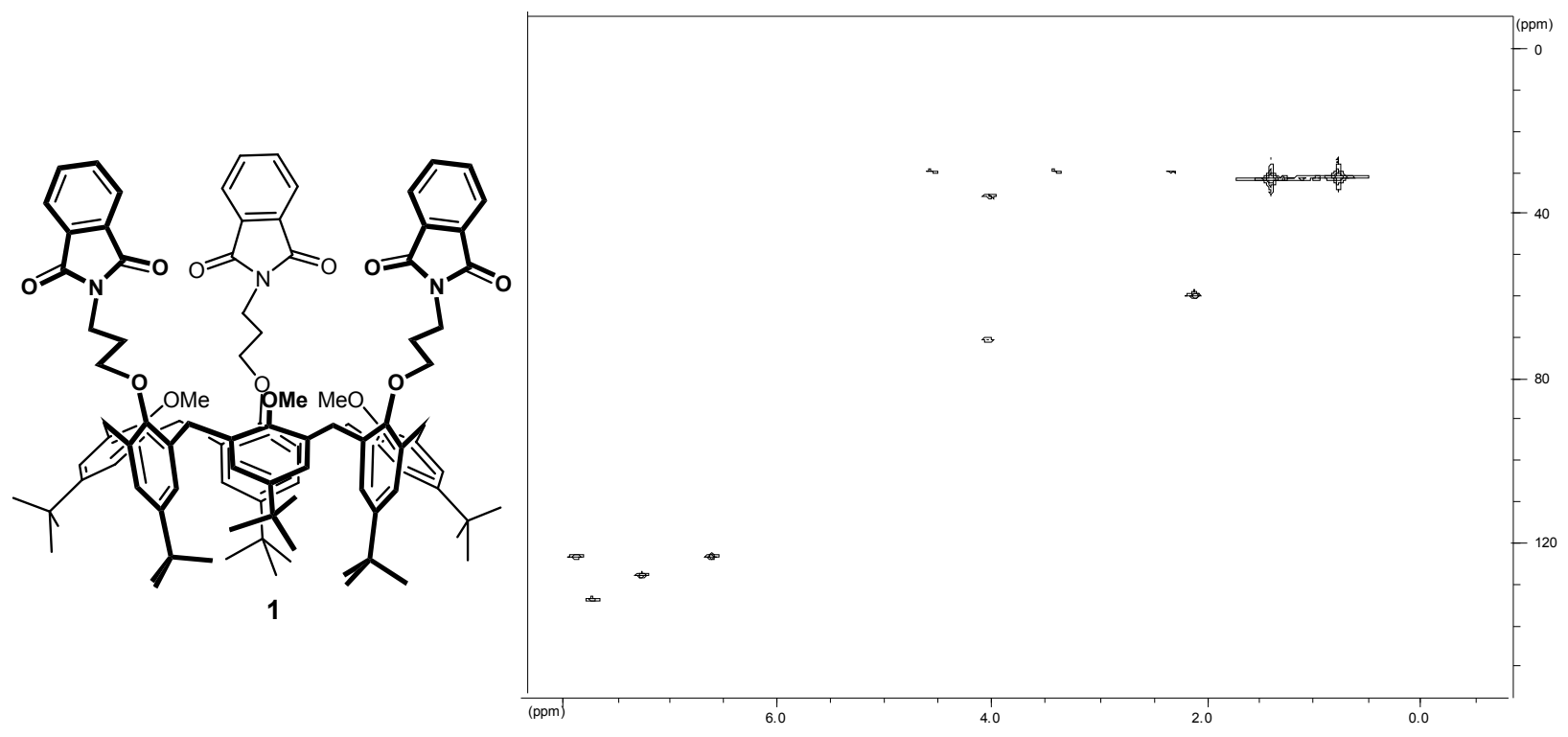

Figure S20. HMQC spectra of 1 recorded at $\mathrm{rt}$ in $\mathrm{CDCl}_{3}$. 


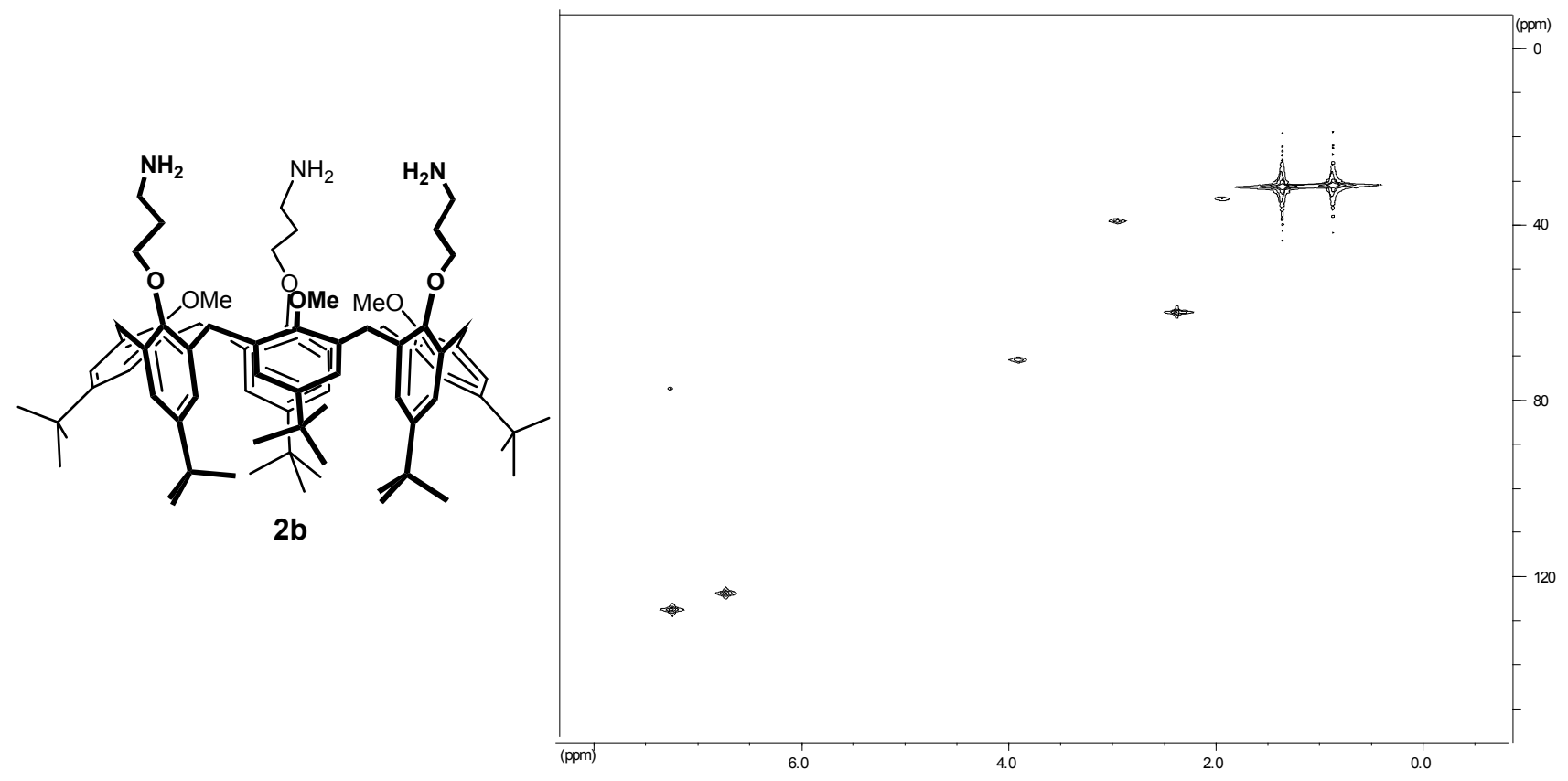

Figure S21. HMQC spectra of $\mathbf{2 b}$ recorded at $320 \mathrm{~K}$ in $\mathrm{CDCl}_{3}$. 


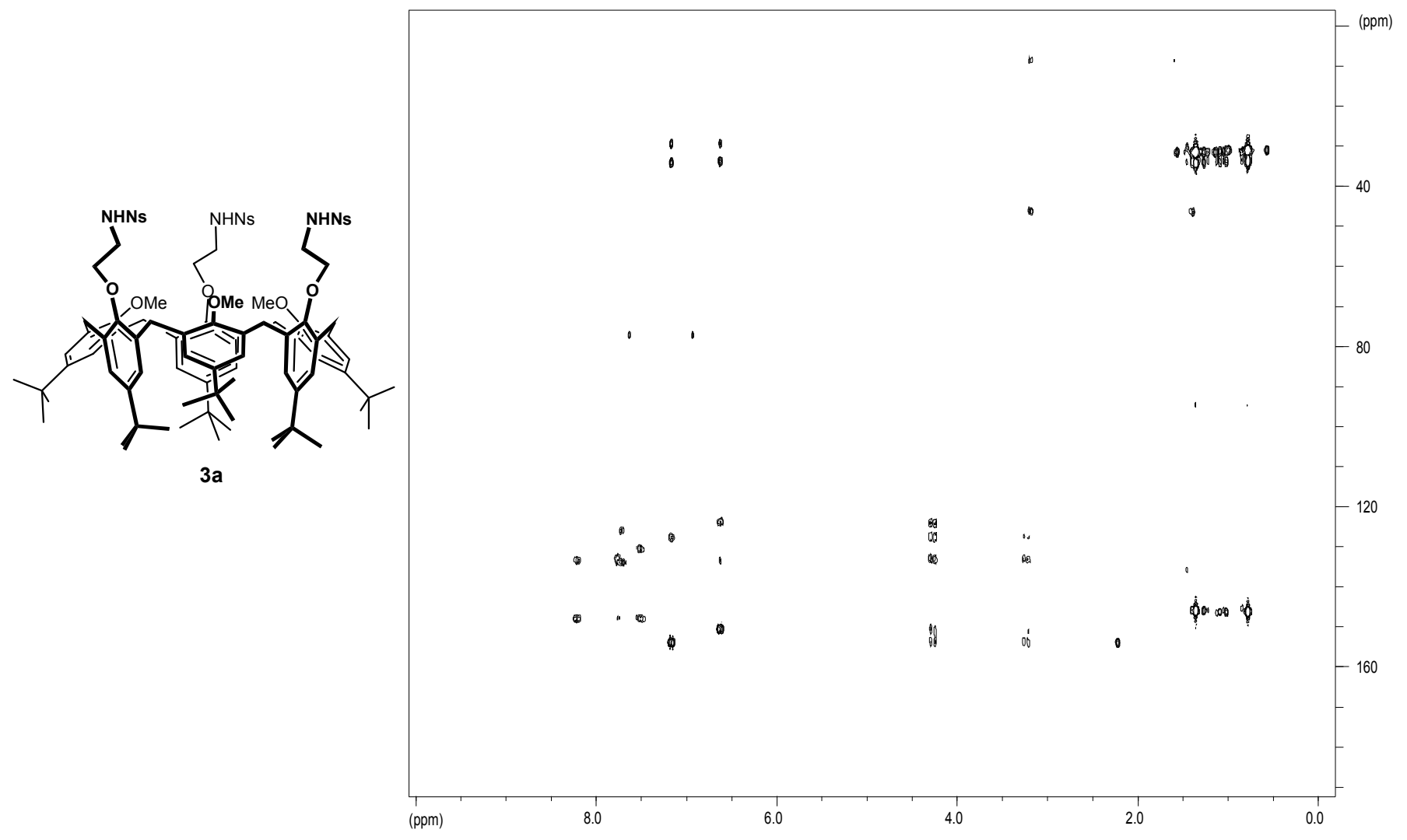

Figure S22. $\mathrm{HMBC}$ spectra of 3a recorded at $\mathrm{rt}$ in $\mathrm{CDCl}_{3}$. 


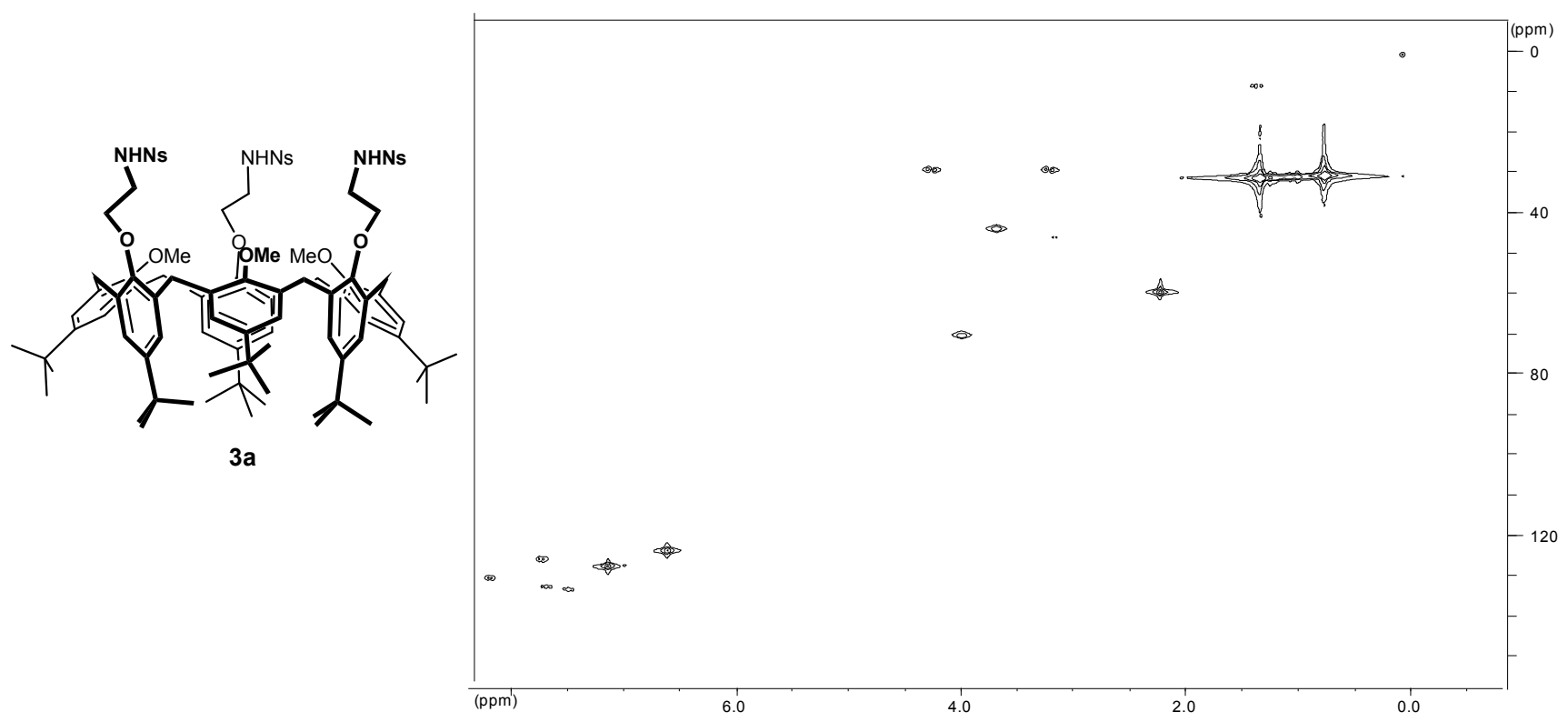

Figure S23. HMQC spectra of 3a recorded at $\mathrm{rt}$ in $\mathrm{CDCl}_{3}$. 


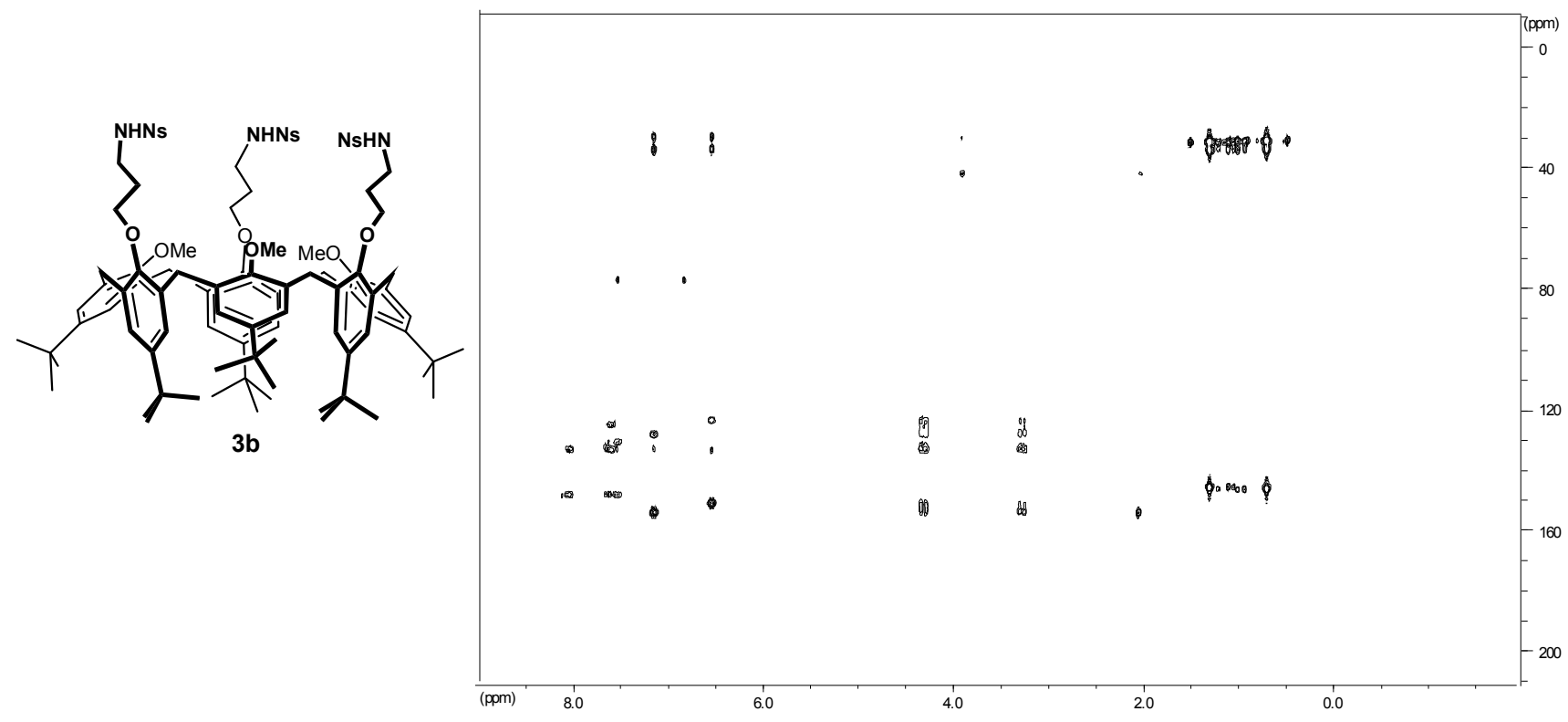

Figure S24. HMBC spectra of $\mathbf{3 b}$ recorded at $\mathrm{rt}$ in $\mathrm{CDCl}_{3}$. 


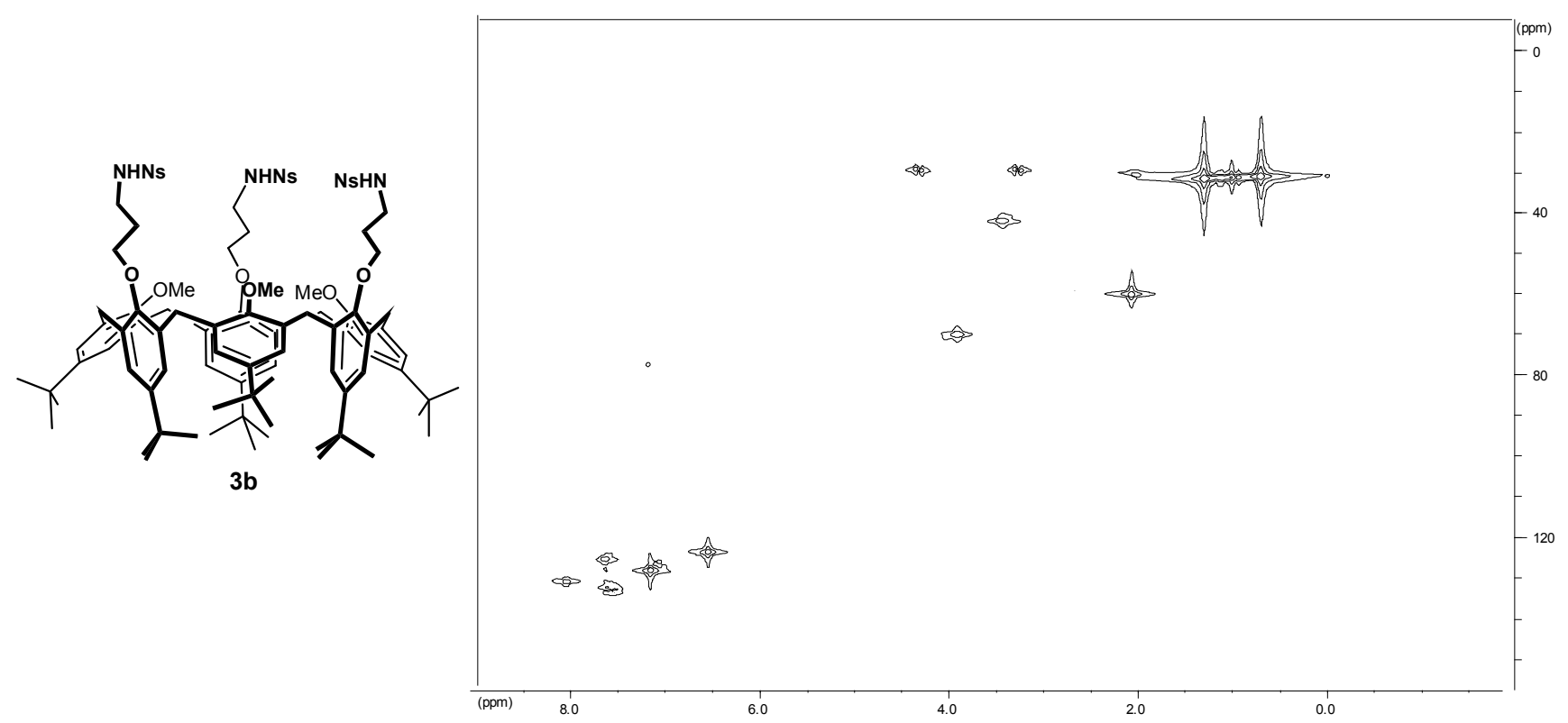

Figure S25. HMQC spectra of $\mathbf{3 b}$ recorded at $\mathrm{rt}$ in $\mathrm{CDCl}_{3}$. 


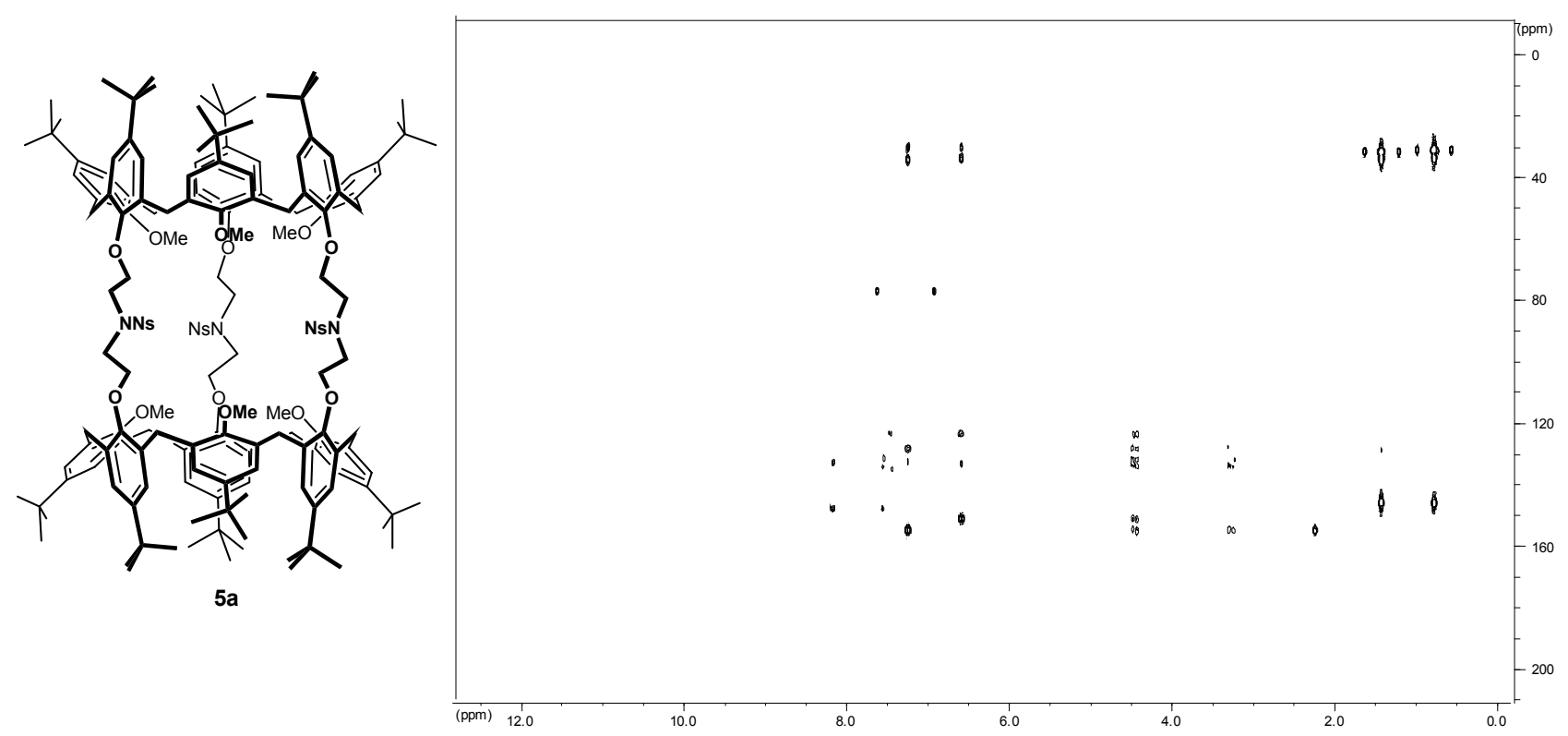

Figure S26. HMBC spectra of $\mathbf{5 a}$ recorded at rt in $\mathrm{CDCl}_{3}$. 


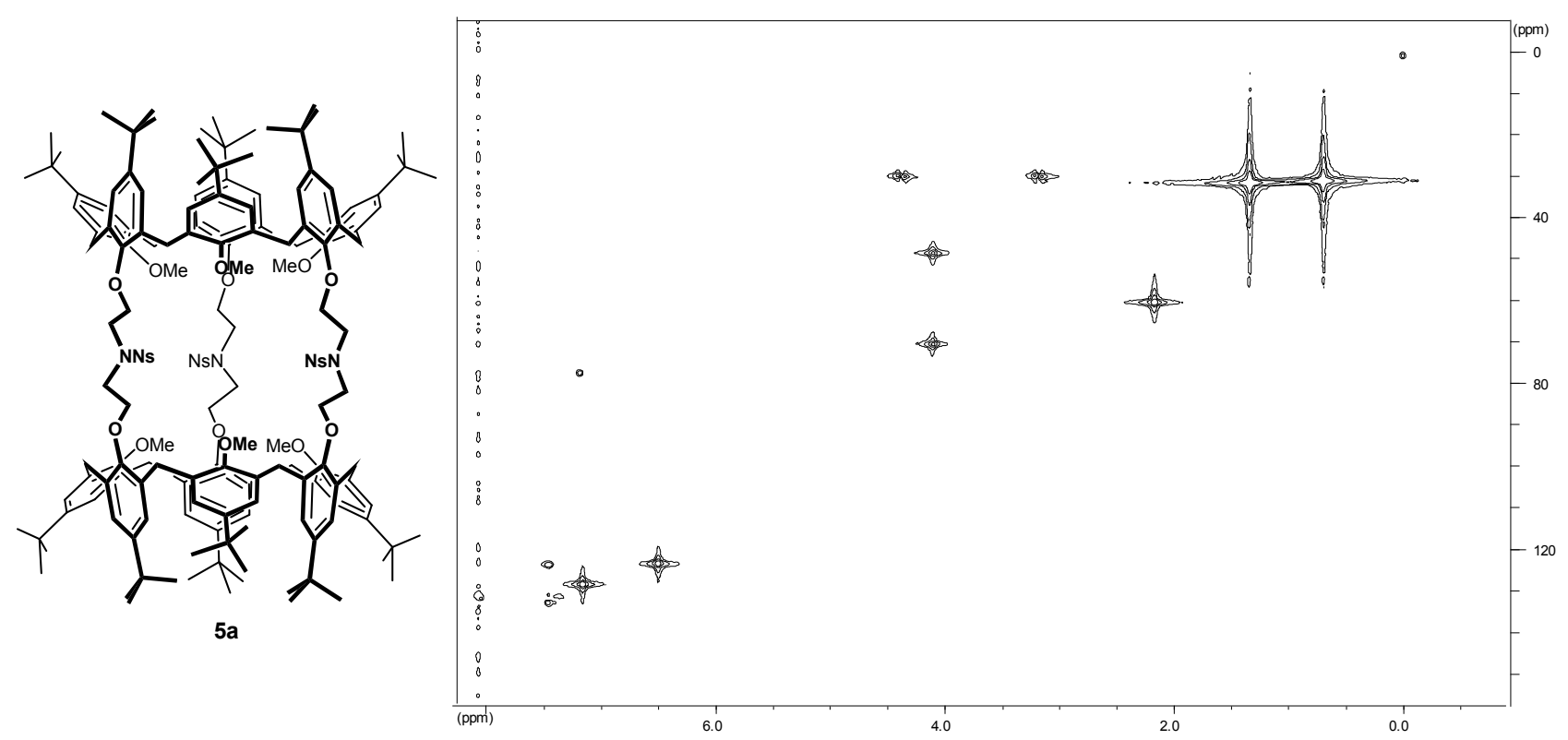

Figure S27. HMQC spectra of 5a recorded at $\mathrm{rt}$ in $\mathrm{CDCl}_{3}$. 


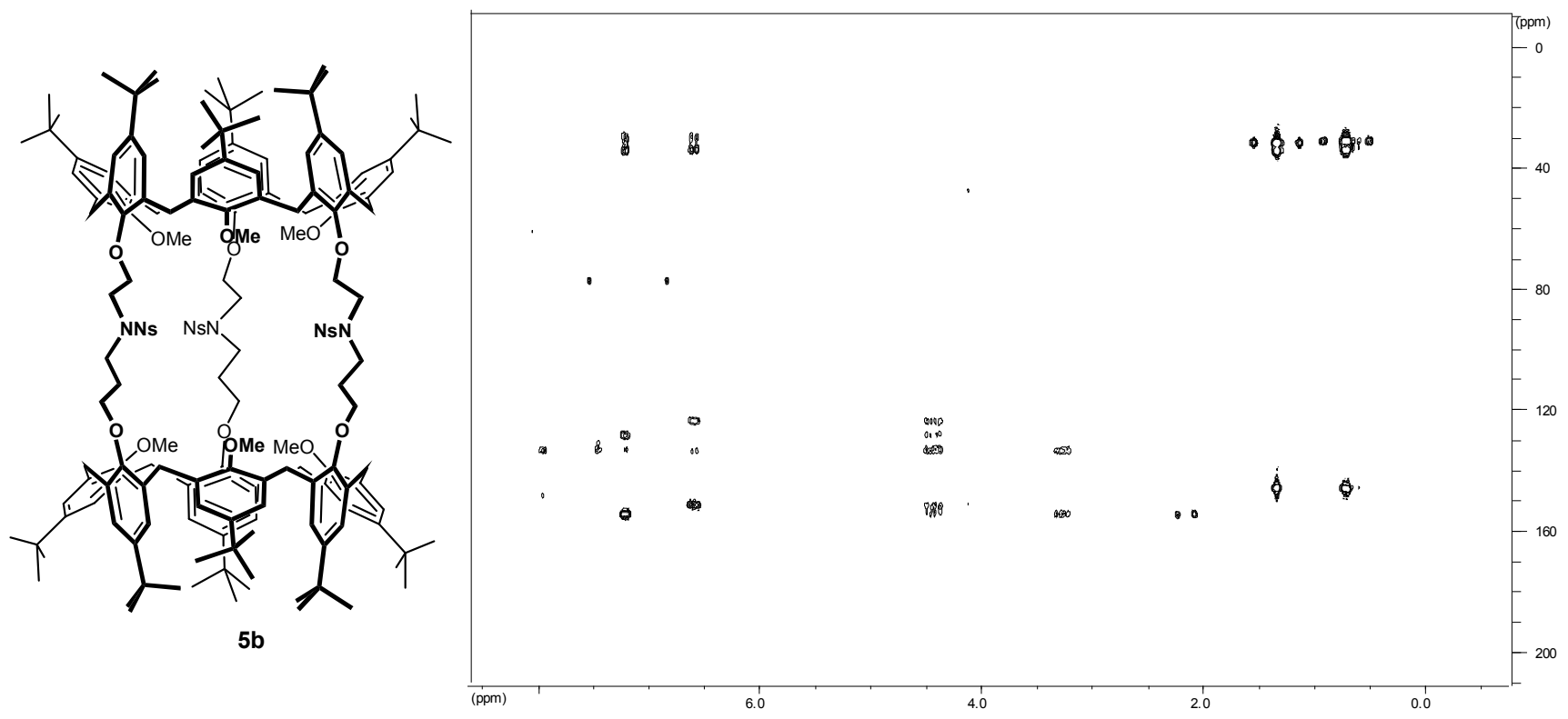

Figure S28. $\mathrm{HMBC}$ spectra of $\mathbf{5 b}$ recorded at $\mathrm{rt}$ in $\mathrm{CDCl}_{3}$. 


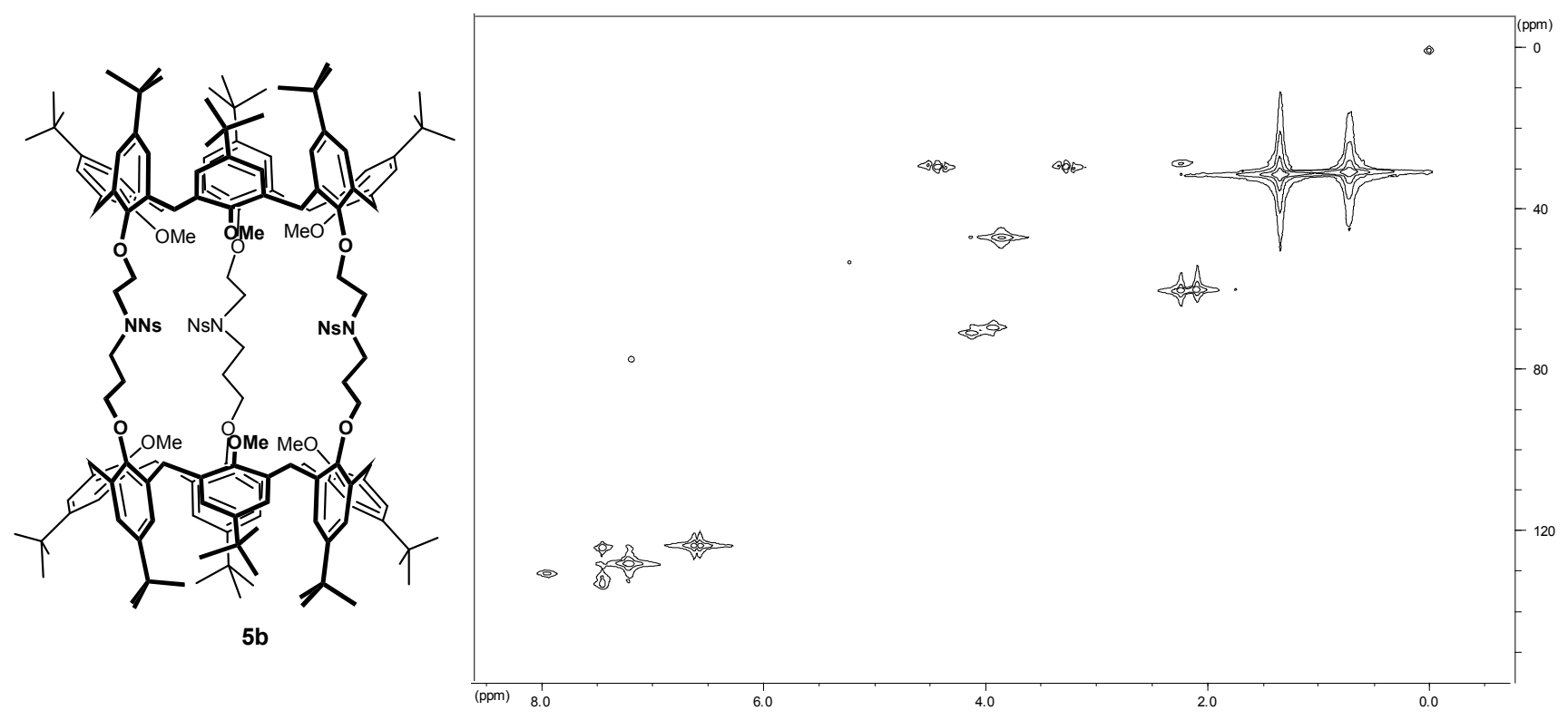

Figure S29. HMQC spectra of $\mathbf{5 b}$ recorded at $\mathrm{rt}$ in $\mathrm{CDCl}_{3}$. 


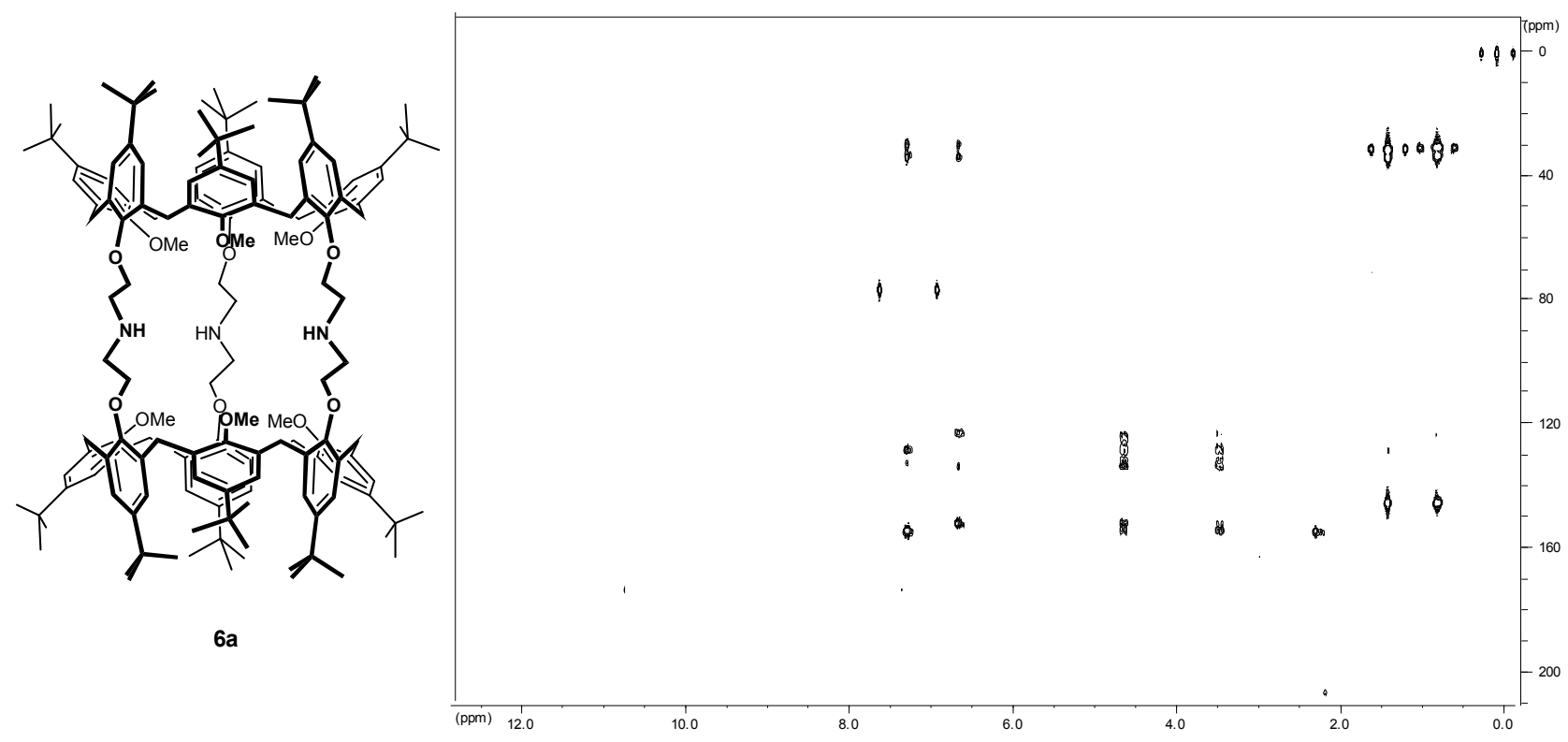

Figure S30. HMBC spectra of $\mathbf{6 a}$ recorded at $\mathrm{rt}$ in $\mathrm{CDCl}_{3}$. 


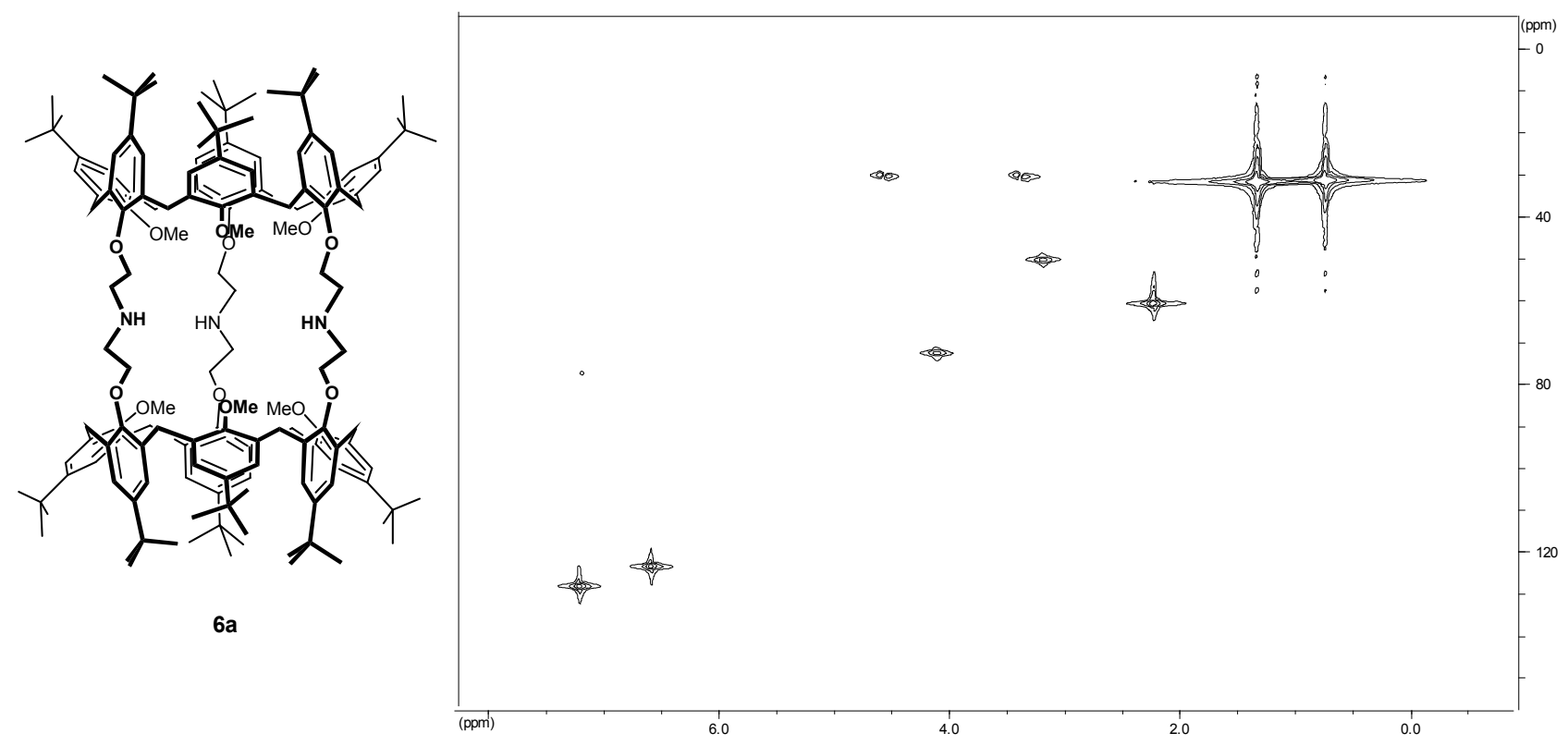

Figure S31. HMQC spectra of $\mathbf{6 a}$ recorded at $\mathrm{rt}$ in $\mathrm{CDCl}_{3}$. 


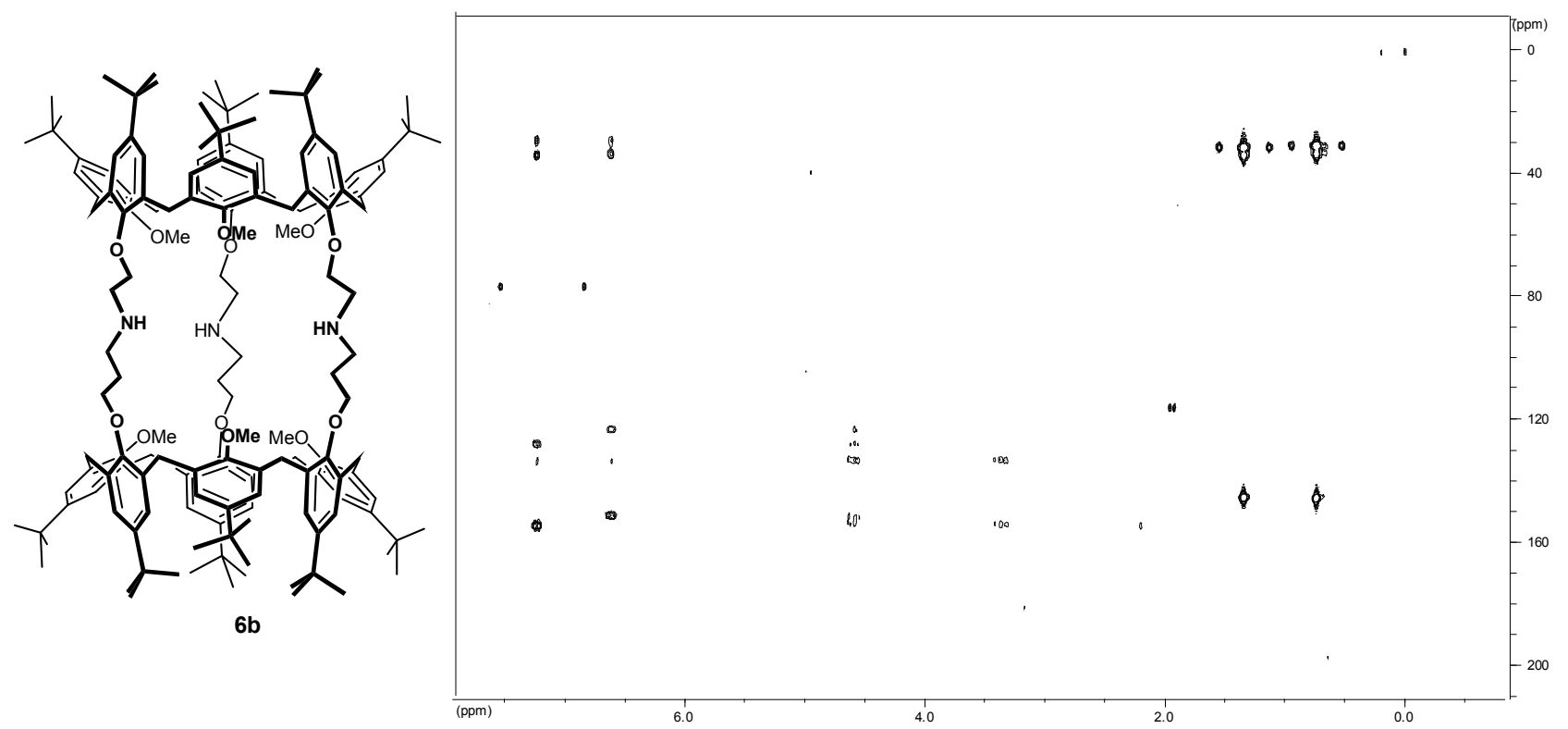

Figure S32. HMBC spectra of $\mathbf{6} \mathbf{b}$ recorded at $\mathrm{rt}$ in $\mathrm{CDCl}_{3}$. 


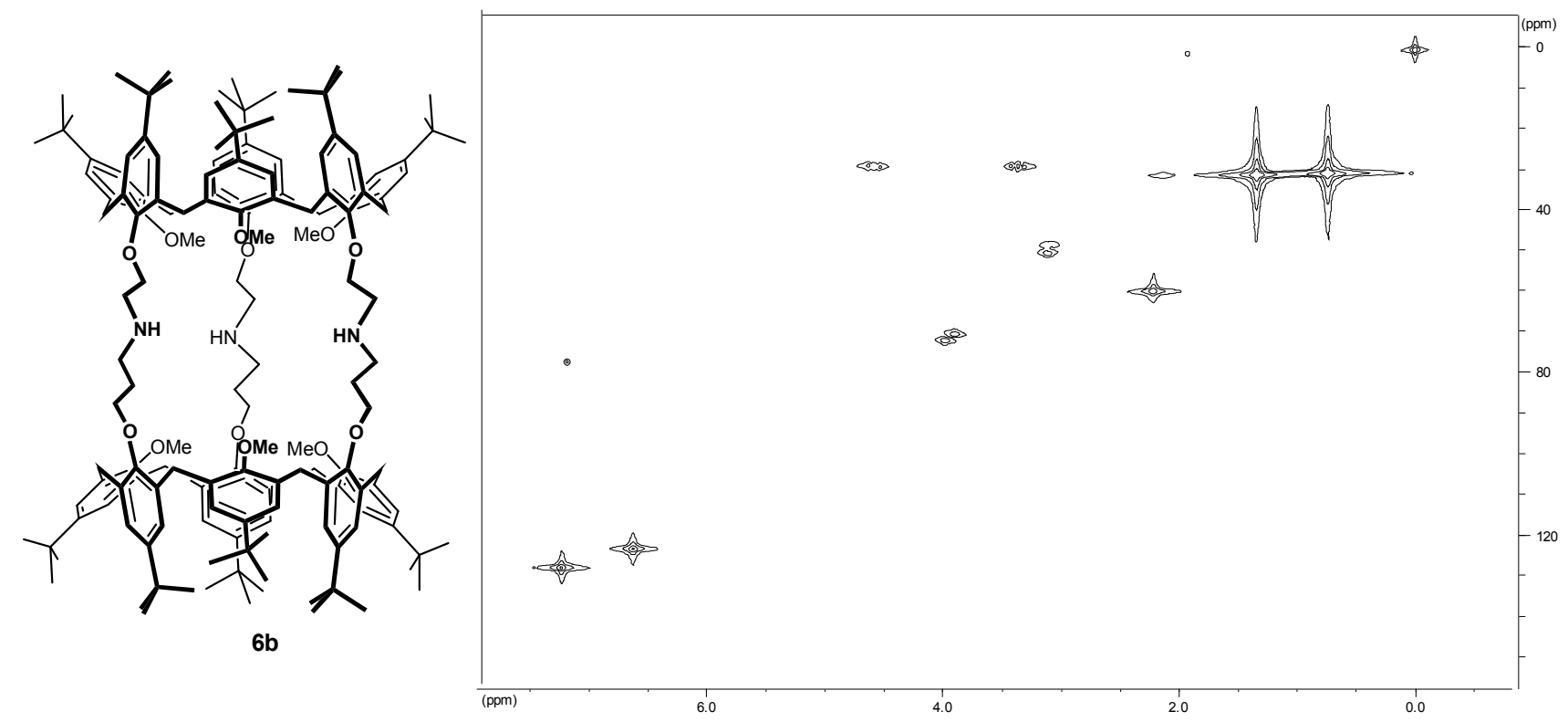

Figure S33. HMQC spectra of $\mathbf{6 b}$ recorded at $\mathrm{rt}$ in $\mathrm{CDCl}_{3}$. 


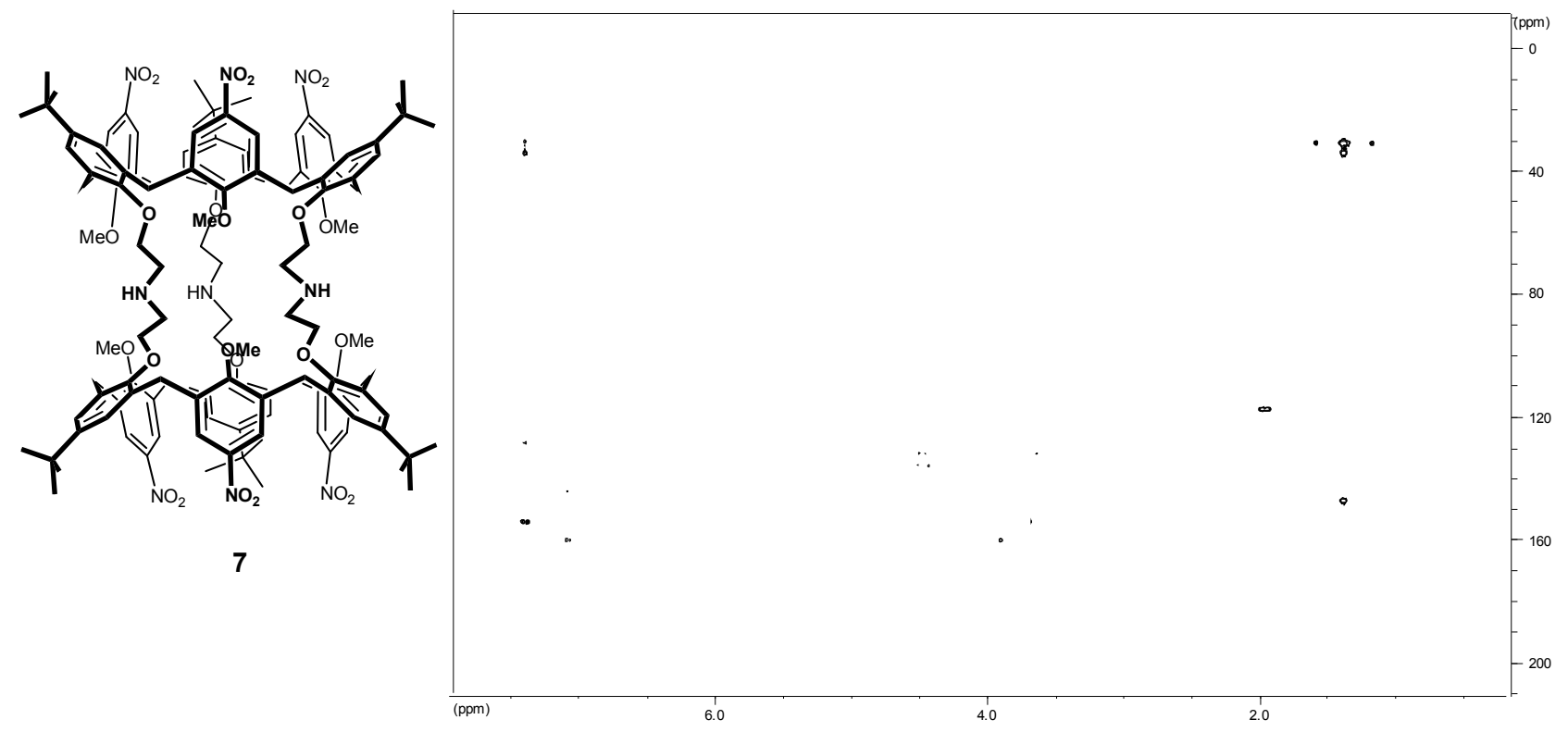

Figure S34. HMBC spectra of 7 recorded at $\mathrm{rt}$ in $\mathrm{CD}_{3} \mathrm{CN}$. 


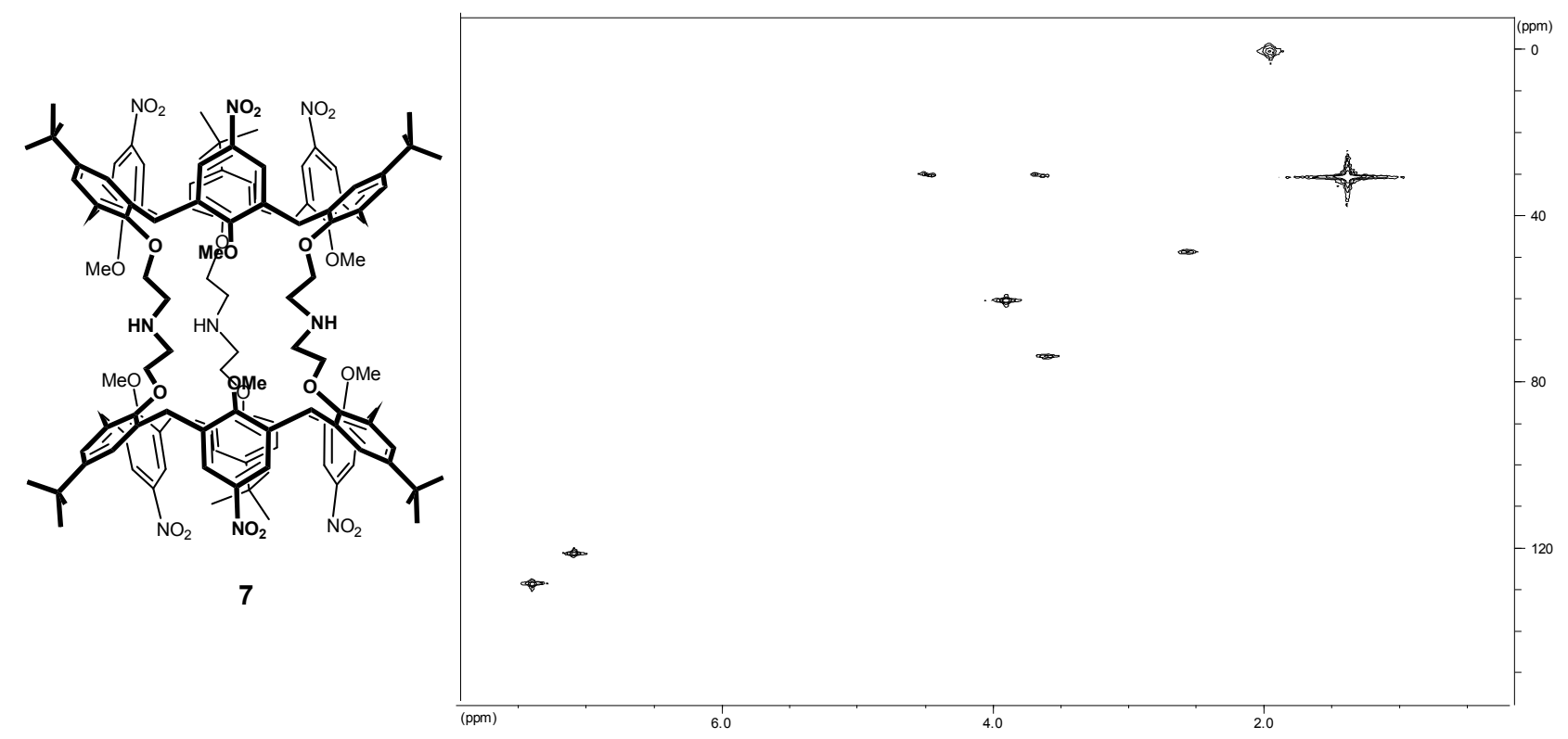

Figure S35. HMQC spectra of 7 recorded at $\mathrm{rt}$ in $\mathrm{CD}_{3} \mathrm{CN}$. 


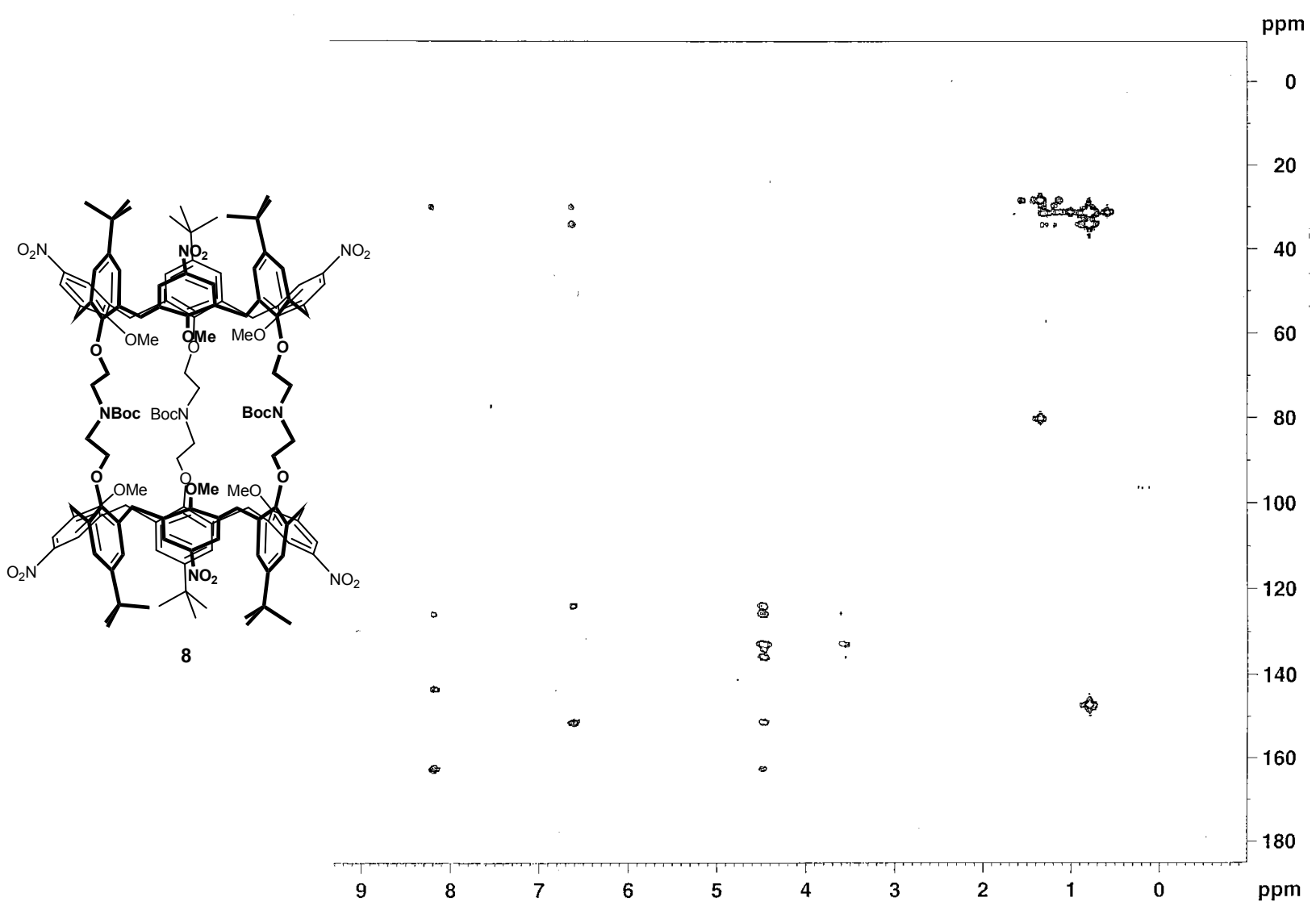

Figure S36. HMBC spectra of 8 recorded at $330 \mathrm{~K}$ in $\mathrm{CDCl}_{3}$. 


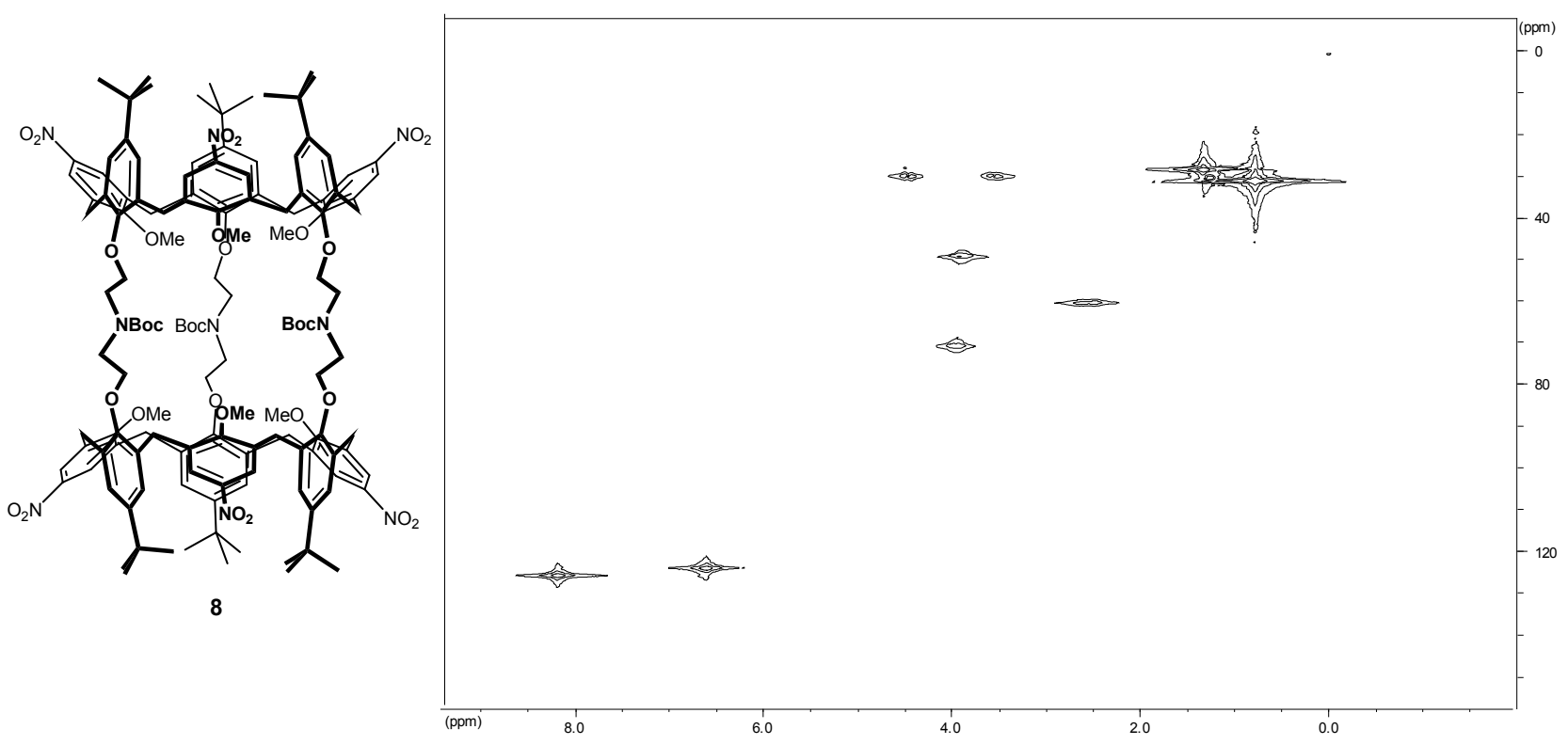

Figure S37. HMQC spectra of 8 recorded at $330 \mathrm{~K}$ in $\mathrm{CDCl}_{3}$. 


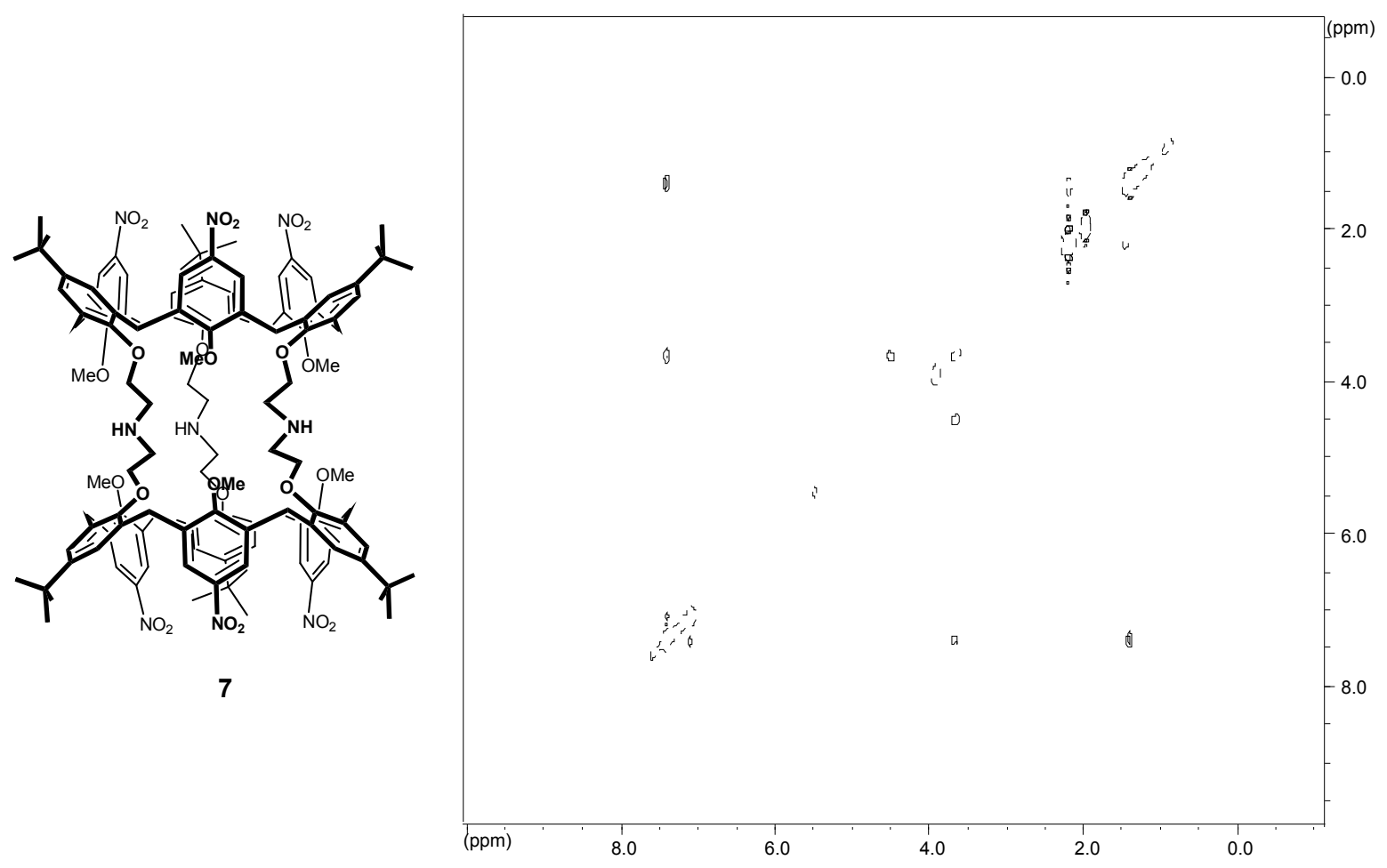

Figure S38. NOESY spectra of 7 recorded at $\mathrm{rt}$ in $\mathrm{CD}_{3} \mathrm{CN}$. 


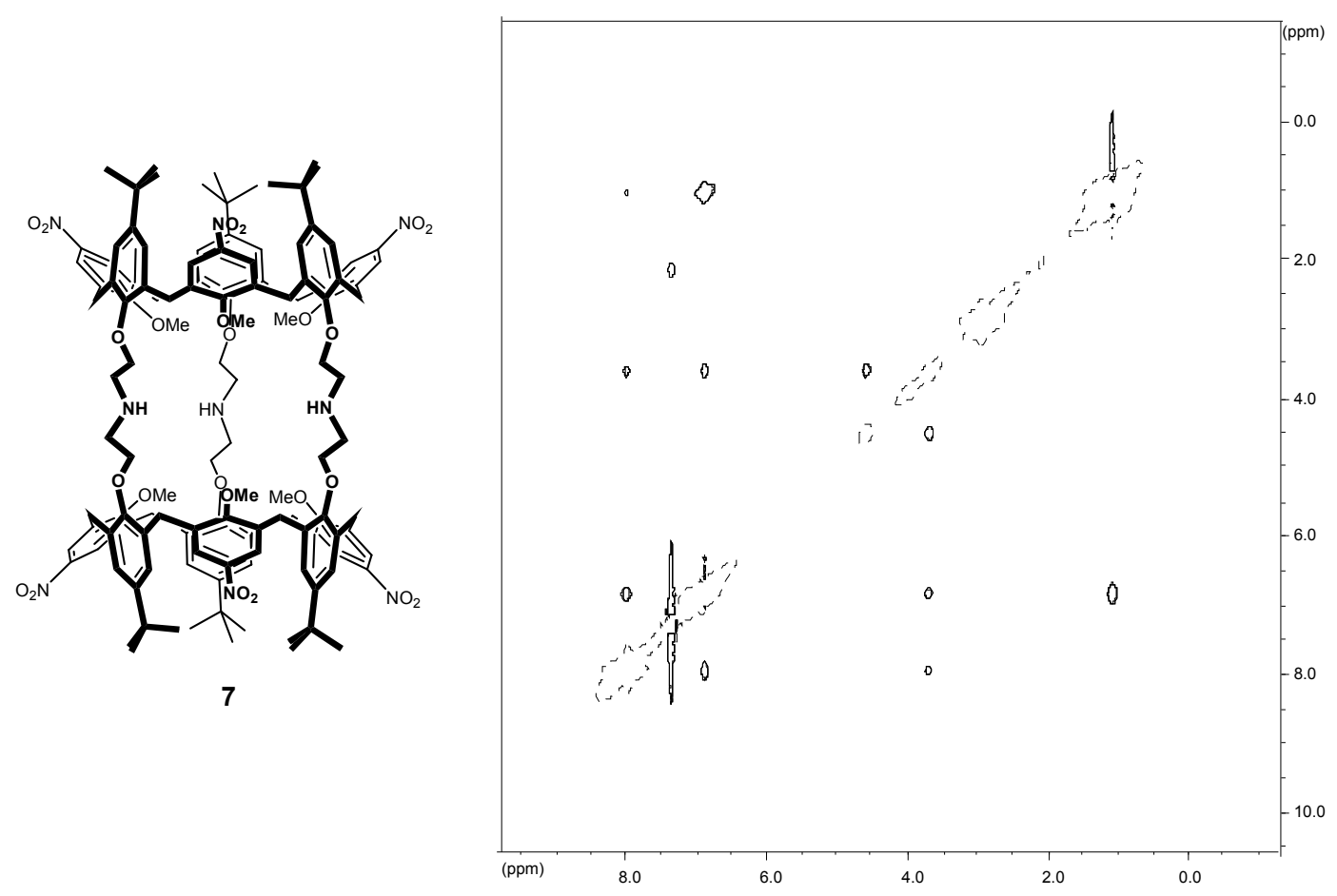

Figure S39. NOESY spectra of 7 recorded at $\mathrm{rt}$ in $\mathrm{CDCl}_{3}$. 
General Experimental Procedures. THF was distilled over sodium/benzophenone under argon. $\mathrm{CH}_{2} \mathrm{Cl}_{2}$ was distilled over $\mathrm{CaH}_{2}$ under argon. DMF was distilled over silica gel/ $\mathrm{MgSO}_{4}$ under argon. All reactions were performed under an inert atmosphere. Silica gel (230-400 mesh) was used for flash chromatography separations. NMR spectra were recorded respectively at 300 or $200 \mathrm{MHz}\left({ }^{1} \mathrm{H}\right)$ and 75 or $50 \mathrm{MHz}\left({ }^{13} \mathrm{C}\right)$. Chemical shifts are expressed in ppm. $\mathrm{X}_{6} \mathrm{H}_{3} \mathrm{Me}_{3}$, compounds $2 \mathbf{a}$ and 4 were prepared according to the reported procedures (See the Theoretical Part for the references). 